Ecosystem Management and Restoration Research Program

\title{
Land and Forest Area Changes in the Vicinity of the Mississippi River Gulf Outlet, Central Wetlands Region, 1935-2010
}

Christina L. Saltus, Glenn M. Suir, and John A. Barras

March 2012 


\title{
Land and Forest Area Changes in the Vicinity of the Mississippi River Gulf Outlet, Central Wetlands Region, 1935-2010
}

\author{
Christina L. Saltus and Glenn M. Suir \\ Environmental Laboratory \\ U.S. Army Engineer Research and Development Center \\ Wetlands and Environmental Technologies Research Facility \\ Louisiana State University - Wetland Resources Building \\ Baton Rouge, LA 70803 \\ John A. Barras \\ U.S. Geological Survey \\ Eastern Geographic Science Center - Baton Rouge Colocation Office \\ Louisiana Office of Coastal Protection and Restoration \\ Baton Rouge, LA 70801
}

Final report

Approved for public release; distribution is unlimited. 


\begin{abstract}
As part of the overall Mississippi River Gulf Outlet (MRGO) Ecosystem Restoration Study, the Central Wetlands Unit (CWU) is a critical coastal restoration project proposed to mitigate the effects of the MRGO dredging and dredged material placement in southeastern coastal Louisiana. An in-depth knowledge of recent and historical coastal landscape history is a key knowledge element required by project managers to make informed decisions for implementing the overall CWU restoration strategy. The goal of this study was to provide a refined landscape history for the CWU that both exceeds and supplements information provided by existing coastal habitat and land loss data sets. The research identified and quantified recent and historical land change trends and general forested wetland habitat changes within the CWU from 1935 to 2010.
\end{abstract}

The CWU land area changes were analyzed using a series of land-water data sets obtained from classified Landsat Thematic Mapper (TM) satellite imagery, historical aerial photography and topographic quadrangles. Wetland forested habitat changes were evaluated using two preconstruction (1935 and 1956) and two post-construction (1965 and 1974) data sets bracketing the construction of the MRGO (1965).

The study revealed that the CWU net land loss from 1935 to 2010 was 6,688 acres with a land area change rate of $-87.6 \pm 11.1 \mathrm{acres} / \mathrm{yr}\left(\mathrm{r}^{2}=0.68\right)$. Rapid loss of forested habitat also occurred within the CWU throughout the 1935 to 1974 analysis period. In 1935, the CWU consisted of 13,924 acres of forested habitat and by 1974 virtually all were lost. The primary events affecting historical landscape change within the CWU over the past 75 years are linked to (1) cumulative hurricane impacts causing physical removal of marsh, (2) partial flooding of impounded areas after Hurricane Betsy, (3) construction of the MRGO, and (4) salinity increases causing habitat conversion.

DISCLAIMER: The contents of this report are not to be used for advertising, publication, or promotional purposes. Citation of trade names does not constitute an official endorsement or approval of the use of such commercial products. All product names and trademarks cited are the property of their respective owners. The findings of this report are not to be construed as an official Department of the Army position unless so designated by other authorized documents. 


\section{Contents}

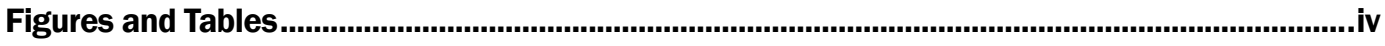

Preface

Unit Conversion Factors................................................................................................................ti

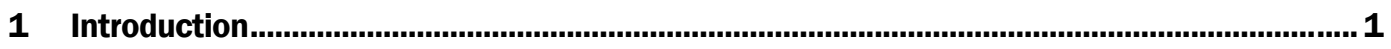

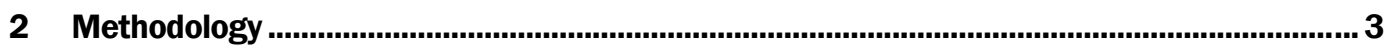

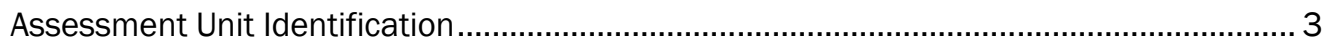

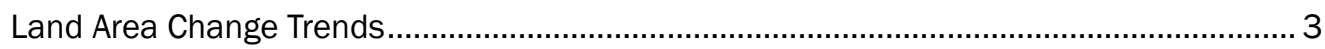

Forested Wetlands Area Change Assessments ............................................................ 5

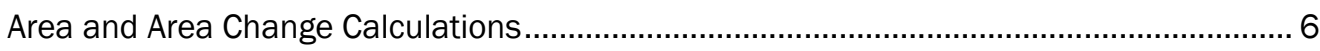

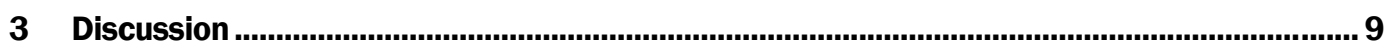

1935 to 2010 Land Change Trends .............................................................................. 9

Recent Linear Regression Trends - 1983-2010 ……..................................................... 10

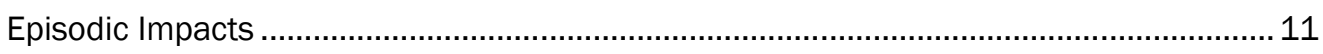

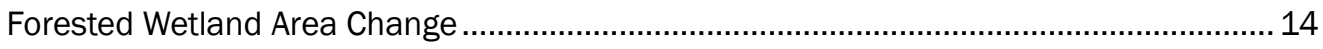

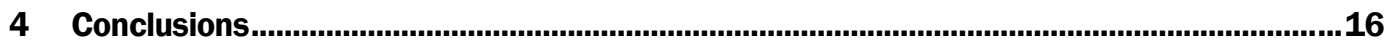

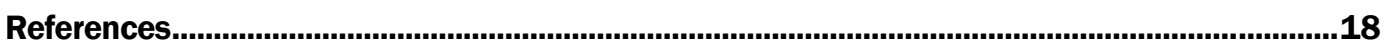

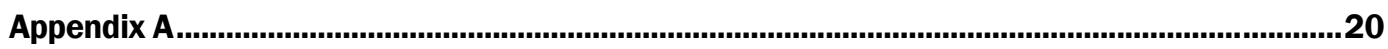

Report Documentation Page 


\section{Figures and Tables}

\section{Figures}

Figure A1. Mississippi Gulf Outlet (MRGO) Model Area................................................................... 27

Figure A2. Mississippi River Gulf Outlet (MRGO) Central Wetlands Assessment Units......................28

Figure A3. Mississippi River Gulf Outlet (MRGO) Central Wetlands Assessment Units, 1935 to 1958 Trends.

Figure A4. Mississippi River Gulf Outlet (MRGO) Central Wetlands Assessment Units, 1958 to 1965 Trends.

Figure A5. Mississippi River Gulf Outlet (MRGO) Central Wetlands Assessment Units, 1965 to 1978 Trends.

Figure A6. Mississippi River Outlet (MRGO) Central Wetlands Assessment Units, 1978 to 1990 Trends.

Figure A7. Mississippi River Gulf Outlet (MRGO) Central Wetlands Assessment Units, 1990 to 2001 Trends.

Figure A8. Mississippi River Gulf Outlet (MRGO) Central Wetlands Assessment Units, 2001 to 2004 Trends.

Figure A9. Mississippi River Gulf Outlet (MRGO) Central Wetlands Assessment Units, 2004 to 2006 Trends.

Figure A10. Mississippi River Gulf Outlet (MRG0) Central Wetlands Assessment Units, 2006 to 2010 Trends.

Figure A11. Mississippi River Gulf Outlet (MRG0) Central Wetlands Assessment Units, 1935 to 2010 Trends

Figure A12. Mississippi River Gulf Outlet (MRG0) Central Wetlands Assessment Units, 1935 to 1956 Forest Area Trends.

Figure A13. Mississippi River Gulf Outlet (MRGO) Central Wetlands Assessment Units, 1956 to 1965 Forest Area Trends.

Figure A14. Mississippi River Gulf Outlet (MRG0) Central Wetlands Assessment Units, 1965 to 1974 Forest Area Trends.

Figure A15. Mississippi River Gulf Outlet (MRGO) Central Wetlands Assessment Units, 1956 Habitats.

Figure A16. Mississippi River Gulf Outlet (MRG0) Central Wetlands Assessment Units, 1978 Habitats.

Figure A17. Mississippi River Gulf Outlet (MRGO) Central Wetlands Assessment Units, 1988 Habitats.

Figure A18. Mississippi River Gulf Outlet (MRGO) Central Wetlands Assessment Units, 2008 Land-Water Data with 2007 Marsh Types.

Figure A19. Mississippi River Gulf Outlet Impoundment Assessment Unit, Pre- and PostHurricane Betsy aerial photography. 


\section{Tables}

Table 1. Central Wetlands Assessment Unit Area.............................................................................. 9

Table 2. Central Wetlands Unit Net Land Area Trends by Period. ...................................................... 10

Table 3. Central Wetlands Assessment Units Land Area Trends by Period. .................................... 13

Table A1. Central Wetlands Unit Net Land Area and Change Trends............................................... 20

Table A2. Central Wetlands Unit - Bayou Bienvenue North Assessment Unit Area and

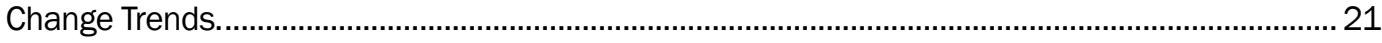

Table A3. Central Wetlands Unit - Forested Wetlands Assessment Unit Area and Change

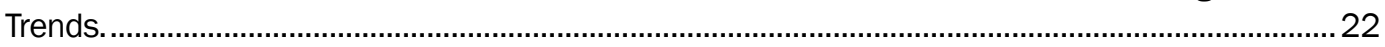

Table A4. Central Wetlands Unit - Hurricane Impact and Marsh Assessment Unit Area and

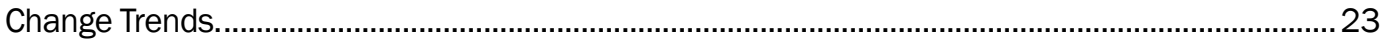

Table A5. Central Wetlands Unit - Impoundment Assessment Unit Area and Change Trends.

Table A6. Central Wetlands Unit - MRGO Dredged Material Placement Assessment Unit

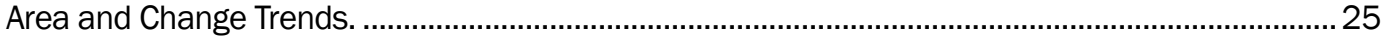

Table A7. Central Wetlands Unit - Assessment Units Forested Area Trends..................................... 26 


\section{Preface}

The research documented in this report was conducted for and funded by the U.S. Army Corps of Engineers, Mississippi River Valley District, New Orleans District, New Orleans, Louisiana as part of the Mississippi River Gulf Outlet Ecosystem Restoration Plan (MRGO) Feasibility Study. The MRGO Feasibility Study was authorized by the Water Resources Development Act of 2007, Section 7013.

The report was published as part of the Ecosystem Management and Restoration Research Program (EMRRP). The EMRRP is sponsored by Headquarters, U.S. Army Corps of Engineers, and is assigned to the U.S. Army Engineer Research and Development Center (ERDC) under the purview of the Environmental Laboratory (EL), Vicksburg, Mississippi. The EMRRP Program Manager is Glenn Rhett.

This report was prepared by Christina Saltus, Glenn Suir, and John Barras, ${ }^{1}$ Environmental Systems Branch (EE-C), ERDC-EL under the general supervision of Mark Graves, Chief, EE-C; Dr. Edmond J. Russo, Jr., P.E., Chief, Ecosystem Evaluation and Engineering Division, EL; and Dr. Beth Fleming, Director, EL.

The authors would like to thank the following individuals for their technical report review comments and suggestions: Gregory B. Miller of U.S. Army Corps of Engineers, New Orleans District; James Johnston and Elizabeth Spalding of PBS\&J Corp; Caroline Lanford of HDR, Inc., and Joshua Carson of Atkins.

At the time of publication of this report, COL Kevin J. Wilson was Commander of ERDC. Dr. Jeffery P. Holland was Director.

The contents of the report are not to be used for advertising or promotional purposes. Citation of brand names does not constitute an official endorsement or approval of the use of such commercial products.

\footnotetext{
1 John Barras is now working for the U.S. Geological Survey, Eastern Geographic Science Center, Baton Rouge Colocation Office, Louisiana Office of Coastal Protection and Restoration, Baton Rouge, LA.
} 


\section{Unit Conversion Factors}

\begin{tabular}{|l|c|l|}
\hline Multiply & By & To Obtain \\
\hline acres & $4,046.873$ & square meters \\
\hline feet & 0.3048 & meters \\
\hline inches & 0.0254 & meters \\
\hline
\end{tabular}




\section{Introduction}

The Mississippi River Gulf Outlet (MRGO) Ecosystem Restoration Plan is a critical coastal restoration project designed to mitigate the effects of the MRGO in southeastern coastal Louisiana. These effects are largely associated with the dredging of the MRGO and the placement of dredged material. The MRGO study area, delineated by means of estimating the area in which habitats have been directly or indirectly impacted by the MRGO, is approximately 2 million acres and is bounded by the Mississippi River and the Inner Harbor Navigation Canal (IHNC) on the west, the Mississippi state border on the east, and the Lake Pontchartrain shoreline to the Fontainebleau State Park on the north (Figure A1). ${ }^{1}$

In an effort to optimize feature assessments and restoration measure application, the MRGO project area was sub-divided into management units. Due to the large expanse of the MRGO study area, the analyses performed and described as part of this report focus entirely on the Central Wetlands Unit (CWU). The CWU is approximately 30,000 acres and is bordered on the west and south by the populated settlements of Lower Ninth Ward, Chalmette, Meraux, Violet, and St. Bernard (Figure A2). Physically, the CWU is bounded by the MRGO on the east, the Gulf Intracoastal Waterway (GIWW) on the north, the back flood protection levees of the Mississippi River on the west, and the back flood protection levees of the St. Bernard Ridge on the south. Being bound by levees and dredged material containment areas on all sides, the CWU hydrologic connectivity has been limited to Lake Borgne inflow via Bayous Bienvenue and Dupre, Mississippi River freshwater inflow via the Violet Siphon (during limited operation from 1979-1983; Louisiana Department of Natural Resources (LDNR), 1992), and forced drainage from surrounding urban areas during rain flooding events.

The purpose of this document is to provide a refined landscape history for the CWU that both exceeds and supplements information provided by existing coastal habitat and land loss data sets. Examination of historical aerial photography, acquired from the 1940 s through the 1970s, provides a means of refining historical land area change timing and magnitude while

${ }^{1}$ For the convenience of the reader, graphics and tabulations illustrating land and forest area changes have been collected in Appendix A. 
identifying and empirically documenting landscape change attributed to episodic events. A refined loss history for the CWU - one that couples loss from episodic events or processes with current high temporal frequency assessments of the modern coastal landscape (Barras et al. 2008; Barras 2009) - provides reliable recent landscape evolution information over a period of analysis (75 years) that is adequate for project planning and implementation.

Specifically, this report summarizes historical changes in forested and land change trends adjacent to the MRGO from 1935 to 2010 using standard data sets routinely used by the US Army Corps of Engineers (USACE) for wetland trend assessments in coastal Louisiana. This report identifies and quantifies: (1) recent and historical land change trends within the MRGO CWU, (2) changes in general forested habitat within the CWU, and (3) habitat impacts associated with the MRGO dredging and dredged material placement. 


\section{Methodology}

\section{Assessment Unit Identification}

A CWU Assessment Unit (AU) data set was created to better identify and assess forest and land change trends within the Central Wetlands Unit. The CWU AUs are aggregates of physiographic units that identify areas of (1) dredged material placement, (2) forest, (3) impoundments, and (4) hurricane impacts. These AUs were digitized on-screen using aerial photography and habitat data sets (Figure A2).

The "Bayou Bienvenue North" AU, (BBN AU) which is located in the northern reach of the CWU, contains dredged material deposited between the GIWW, the northern terminus of the MRGO, and Bayou Bienvenue. A second dredged material placement AU, the "MRGO Dredged Material Placement Area" (MRGO DMP AU), contains the MRGO dredged material deposition area extending south from Bayou Bienvenue along the MRGO to the far southeastern section of the CWU. United States Geological Survey (USGS) topographic quadrangles from the late 1930 s were used to delineate the "Forested Wetlands AU" (FW AU) located at the southwestern reach of the CWU. The FW AU defines a region of historical forest habitat consisting primarily of cypress-tupelo forest bordering the hurricane-impacted areas to the northeast, and portions of the MRGO dredged material placement area to the east. The triangular area between Bayou Bienvenue, the Forty Arpent Canal, and Paris Road, makes up the "Impoundment Area" AU (IA AU). This AU consists of outfall-related impoundments in the west and an area of impounded marsh in the east that is bounded by the BBN AU and Paris Road. Lastly, the "Hurricane Impact and Marsh Area" AU (HIMA AU), located in the central portion of the CWU and almost entirely bounded by the other AUs, consists primarily of marsh that sustained significant historical hurricane impacts.

\section{Land Area Change Trends}

Land change trends discussed in this report were calculated using landwater data sets developed for prior coastal land area change assessments (Barras et al. 1994, 2003, 2008 and Barras 2006, 2009), as well as newly created land-water data sets. These data sets were derived from (1) Landsat Thematic Mapper (TM) satellite imagery obtained from the USGS Center 
for Earth Resources Observation and Science (EROS) and then classified by land-water coverage, (2) modified photointerpreted National Wetlands Inventory (NWI) data created for wetland habitat classifications, and (3) land-water data sets photointerpreted from panchromatic and color infrared (CIR) aerial photography. Additional assessments, those that compared CWU trends to regional trends within the MRGO ecosystem area, were based on the coastal data sets and comparison intervals used in Barras et al. (2008).

From 1983 through the present, Landsat TM moderate spatial resolution ( $25 \mathrm{~m}$ or $82 \mathrm{ft}$ ) satellite imagery has provided a same area return frequency of 16 days. The higher temporal frequency and greater spectral resolution of the Landsat TM imagery is useful for estimating short-term land area variation linked to hurricane-induced episodic loss and/or prevailing environmental conditions (Barras 2006, 2007). However, assessing historical land change trends within the CWU before 1983 (prior to Landsat TM 5 satellite imagery collection), and linking those changes to specific events, may not be possible without examining aerial photography bracketing prior episodic events and the construction of the MRGO (1965). Misinterpretation of the possible causes of localized loss linked to episodic events, based on decadal or greater comparison periods, may lead to the recommendation and application of inappropriate or ineffective restoration solutions. Therefore, quantifying these changes required developing additional photointerpreted land-water data sets from historical photography. The labor-intensive and time-consuming photointerpretation process is required to increase temporal frequency, which in turn provides a clearer understanding of land area change timing and magnitude within key restoration areas.

The CWU AU land area changes were analyzed using a sequential series of 40 land-water data sets obtained from 1935 to 2010. The existing coastal land-water data sets were supplemented by land-water data sets developed for regional trend assessments of the deltaic plain (Morton et al. 2005) and for 2008 hurricane assessments (Barras 2009). Two additional Landsat TM scenes were classified to provide 2009 and 2010 land-water estimates for the CWU. The additional classified Landsat data sets provided a more robust estimate of recent 1983 to 2010 land area changes within the CWU. Four new historical land-water data sets were interpreted for the CWU. They include the 1935 USGS 1:24,000 topographic maps, 1958 Tobin panchromatic quadrangle photo mosaic, 1965 Tobin panchromatic 
photography, and 1974 National Aeronautics and Space Administration CIR photography.

These additional historical data sets were selected and classified to increase the CWU comparison period to 75 years, and to provide comparison intervals that bracket construction of the MRGO. Visual comparison of the 1958 Tobin photo mosaic to the NWI 1956 habitat data suggested that the 1956 NWI data underestimated water area within the HIMA AU. The 1958 Tobin data were interpreted to provide a better estimate of historical land area changes between 1935 and 1958, and to provide land-water area within the CWU immediately prior to MRGO construction. The 1965 and 1974 photography provided immediate and decadal post-MRGO construction land area estimates. The historical data sets were classified to identify landwater using the same methodology described in Morton et al. (2005). The data sets were then resampled to $82 \mathrm{ft}$ for spatial consistency with the existing land-water data sets.

\section{Forested Wetlands Area Change Assessments}

Forested wetland changes bracketing the construction of the MRGO (1965) were evaluated using two pre-construction (1935 and 1956) and two postconstruction (1965 and 1974) data sets based on habitat classification, temporal range, and comparability. Identifying these changes within the CWU required standardization of forested wetland habitat across the four data sets. For this study, forested wetland habitat was defined as predominantly cypress and tupelo swamp, but included other swamp forest species. Limited amounts of bottomland hardwoods were likely present in the IA and BBN AUs. The FW and HIMA wetland forest habitat consisted primarily of cypress and tupelo.

The 1935 forested wetland and hydrography data (USGS 1951) utilized in this report consist primarily of habitat features that originated from 1935 surveys, but contain a small region (approximately 250 acres within the Delacroix quadrangle) of wetland forest that was delineated during a 1938 survey. The 1935 forested wetland classification was created by joining the wooded marsh and woodland habitat types (symbolized on the historical USGS topographic quadrangles) to delineate the forested wetland habitat. The 1935 forested wetlands data were then used as the historical baseline for tracking forest habitat conversion or loss over time. The 1956 habitat data set was aggregated from source NWI habitat data based on Cowardin et al. (1979) and further consolidated by Wicker (1980). The forest and 
swamp classes, which consisted of bottomland hardwoods, cypress, tupelo, swamp maple, and willow, were combined to create the $1956 \mathrm{CWU}$ forested wetland classification. The 1965 forested wetlands extent was visually interpreted using the 1965 panchromatic aerial photography and other auxiliary data. Visual assessment of the 1974 color infrared aerial photography showed that no significant forested wetlands were present. However, it is included in the analysis to demonstrate rapid habitat transition within the CWU after construction of the MRGO.

Habitat alterations as a result of the MRGO channel dredging and dredged material placement within the CWU were assessed utilizing the previously mentioned data sets $(1935,1956,1965$, and 1974). Although dredged material was placed in the BBN AU (bordering the GIWW and the limited extent of the MRGO north of Bayou Bienvienue), the primary focus of the dredged material change analysis was the dredged material deposited directly adjacent to the MRGO channel within the MRGO Dredged Material Placement AU. The MRGO dredged material deposition area was defined using 1965 post-construction aerial photography. This area of dredged material placement was bounded on the east by the MRGO Canal, the north by Bayou Bienvenue, the west by the containment levee, and on the south by the St. Bernard ridge. Additional dredged material was placed on the southwest section of the MRGO DMP AU between 1965 and 1974 and was delineated using 1974 color infrared aerial photography.

Composite data sets were created by merging the forested wetland and dredged material placement classifications with the land and water habitats interpreted for each temporal data point. Due to the underestimation of water area in the 1956 NWI data, the $195^{8}$ water data were utilized in its place. The forested wetland and MRGO dredged material deposition change assessments were then analyzed by AU to determine net area changes based on four classification types: (1) land, (2) water, (3) forested wetlands, and (4) dredged material placement.

\section{Area and Area Change Calculations}

The CWU AU data set was digitized in a vector polygon format using ESRI ArcGIS® software (Environmental Systems Research Institute, Redlands, $\mathrm{CA}$ ). The vector dataset was then converted to a raster format with a minimum pixel spatial resolution of $82 \mathrm{ft}$ x $82 \mathrm{ft}$ ( $25 \mathrm{~m} \mathrm{x} 25 \mathrm{~m}$ ) for consistency with existing data used for prior Louisiana land change assessments (Barras et al. 2008). The ERDAS IMAGINE® software (Leica Geosystems 
Geospatial Imaging, LLC, Norcross, GA, 2007) SUMMARY function was used to generate assessment unit area statistics for habitat and land-water data sets. Assessment Unit summaries were derived from the source assessment unit statistics. Prism ${ }^{\mathrm{SM}}$ version 5.ob for Macintosh (GraphPad Software, San Diego, CA) was used for linear regression-based trend analyses (Barras et al. 2008).

For the land and forest change analyses, representative sequential data pairs were analyzed using the ERDAS IMAGINE MATRIX function. All gain and loss areas within the resulting change data sets were then filtered using the NEIGHBORHOOD function. This process smoothes the image (eliminating the "salt and pepper" noise), and reduces the edge effect that often occurs with slightly misaligned images. The filtered gain and loss images were joined with the respective end-point land-water images using the OVERLAY function.

Land and water area from 1935 to 2010 was summarized for the CWU (Table A1) and for each AU (Tables A2-A6). The land area measurements were then used to calculate net land losses or gains by comparison period and annual trend rates by period (Tables A1-A6). For consistency, net loss was calculated by periods used in Barras et al. (2008). Additional historical comparison intervals measuring net loss between 1935 and 1958, 1958 and 1965, and 1965 and 1978 were added to refine the historical loss magnitude and timing within the CWU. The 1974 data set was not used for calculating net land area trends since the photography was acquired two days after Hurricane Carmen (September 8, 1974), which delivered 3-5 in. of rain (up to 7.8 in. in Boothville) in southeastern Louisiana. As an alternative, the 1978 habitat-based NWI data were collapsed into land-water classes for inclusion in the land-water analyses.

Linear regression analysis provided a more robust estimate of recent trends within the CWU from 1983 to 2010 by comparing land area over time using all available higher temporal frequency data sets. The quantity of available data sets after 1983 includes classified images acquired under varying tidal and meteorological conditions that contribute to short-term variance in land area measurements. Calculating net trends using only two data points may skew annualized loss rates. For example, a comparison period based on a start date using a classified low water level image compared to an end date based on a high water level image will result in a greater loss estimate for the period and higher projected loss rates. High 
coefficient of correlation values $\left(\mathrm{r}^{2}\right)$ indicate constant land area decrease with time, implying that the loss rate may be suitable for short-term future projections. A low $\mathrm{r}^{2}$ value indicates that either the area has remained stable during the 1983 to 2009 period or that loss is not constant with time and may be related to episodic events or other nonlinear events.

Changes in land area include both permanent and transitory losses and gains caused by local and regional environmental factors occurring at the time images were acquired. The time-dependent factors that affect landwater classification include water level variations caused by different tidal and meteorological conditions, possible misclassification of aquatic vegetation and flats, and seasonal variations in marsh growth cycles. Though these limitations occur, the temporal resolution of the TM imagery allows for selection of optimal condition data sets, therefore reducing those time-dependent influences. 


\section{Discussion}

\section{5 to 2010 Land Change Trends}

The land loss trend methodology uses a combination of new and existing data sets and trend assessment techniques (Barras et al. 2008). The CWU accounts for $1.6 \%$ of the total MRGO area of 2,000,826 acres and $0.6 \%$ of the deltaic plain's 5,078,412 acres. Total net land loss for the CWU from 1958 (photography) to 2006 (TM; October 26, 2006) is 4,638 acres and accounts for $3.8 \%$ of the total MRGO net loss of 123,183 acres and $0.7 \%$ of the deltaic plain's net loss of 630,388 acres (Barras et al. 2008). The MRGO DMP, HIMA, BBN, FW, and IA AUs account for 21\% (6,569 acres), $28 \%$ (8,910 acres), $11 \%$ (3,594 acres), 29\% (9,253 acres), and $11 \%$ (3,550 acres) of the total CWU area respectively (Table 1). From 1935 to 2010, the net CWU loss was 6,688 acres. The MRGO DMP net loss (805 acres), HIMA net loss (2,314 acres), BBN net loss (691 acres), FW net loss (505 acres), and IA net loss (2,373 acres) accounted for $12 \%, 35 \%, 10 \%, 8 \%$, and $35 \%$ of the CWU's total loss, respectively (Table A3 and Figure A11).

Table 1. Central Wetlands Assessment Unit Area.

\begin{tabular}{|l|l|l|}
\hline Assessment Unit & Acres & $\%$ Total Area \\
\hline MRGO Dredged Material Placement Area (MRGO DMP) & $6,568.5$ & $21 \%$ \\
\hline Hurricane Impact and Marsh Area (HIMA) & $8,909.9$ & $28 \%$ \\
\hline Bayou Bienvenue North (BBN) & $3,593.7$ & $11 \%$ \\
\hline Forested Wetlands (FW) & $9,253.2$ & $29 \%$ \\
\hline Impoundment Area (IA) & $3,549.7$ & $11 \%$ \\
\hline Total & $31,875.0$ & $100 \%$ \\
\hline
\end{tabular}

Examining net loss by period for the CWU provides a better idea of the timing and magnitude of historical and recent land area changes (Table 2). Over the last 75 years the assessment interval that accounted for the largest percentage of land area change within the CWU was the 1935-1958 period. The 1947 Fort Lauderdale Hurricane (September 19, 1947), a category 1 storm, directly impacted the CWU during this period. The 1958-1965 period encompassed the construction of the MRGO, which resulted in land gain from dredged material deposition and land loss from the dredging of the MRGO channel. The 1965-1978 period incurred the second greatest loss, followed by the 2004-2006 period. These increases in net loss were due 
primarily to the direct impacts of Hurricane Betsy (September 10, 1965), a category 4 storm, and Hurricane Katrina (August 29, 2005), a category 3 storm, respectively (Barras 2006, 2007). The 2006-2010 period's gain of 638 acres is partially related to the end point classified Landsat TM image of February 25, 2010 reflecting lower water level conditions, possible partial recovery after Hurricane Katrina, and normal land area classification variation. The 1978-2004 period contained no major hurricane landfalls affecting the CWU, was characterized as stable with moderate land change, and accounted for $18 \%$ of the CWU total loss. During this period, the IA and HIMA AUs were characterized by continued loss of brackish marsh.

However, the IA AU lost much of its remaining brackish marsh during this period since it was less resistant to degradation than the HIMA AU marsh. Most loss during the 1978-1990 period was concentrated in submerging brackish marsh located within the northeastern section of the IA AU (Figure A6). The 1990-2001 losses were concentrated on the fringes of existing brackish ponds within IA and HIMA AUs (Figure A7). While the majority of the 2001-2004 losses were similar to the 1990-2001 losses, reflecting continued slow loss of brackish marsh, some losses likely reflect the temporary retainment of water within the MRGO DMP AU (Figure A8).

Table 2. Central Wetlands Unit Net Land Area Trends by Period.

\begin{tabular}{|l|l|l|l|}
\hline Interval & Net Loss (Acres) & Period (Years) & Percent Total Change \\
\hline $1935-1958$ & $-2,688$ & 23 & $-40.2 \%$ \\
\hline $1958-1965$ & -606 & 7 & $-9.1 \%$ \\
\hline $1965-1978$ & $-1,864$ & 13 & $-27.9 \%$ \\
\hline $1978-1990$ & -421 & 12 & $-6.3 \%$ \\
\hline $1990-2001$ & -565 & 11 & $-8.4 \%$ \\
\hline $2001-2004$ & -217 & 3 & $-3.2 \%$ \\
\hline $2004-2006$ & -965 & 2 & $-14.4 \%$ \\
\hline $2006-2010$ & 638 & 4 & $9.5 \%$ \\
\hline Total & $-6,688$ & 75 & $-100.0 \%$ \\
\hline
\end{tabular}

\section{Recent Linear Regression Trends - 1983-2010}

Recent land area trends (1983-2010) were calculated for the CWU and associated AUs using 32 classified Landsat TM land-water data sets and simple linear regression. Data sets containing outlying high and low water levels, and partial cloud cover were excluded from the linear regression trend analyses. The land area change rate for the CWU is $-87.6 \pm 11.1$ 
acres $/ \mathrm{yr}\left(\mathrm{r}^{2}=0.68\right)$. Over the same period of analysis, and using the same data points, the Central Wetlands AUs experienced change rates of $-8.3 \pm$ 0.6 acres $/ \mathrm{yr}\left(\mathrm{r}^{2}=0.85\right)$ for the BBN AU (Table A2), $-18.1 \pm 4.2$ acres $/ \mathrm{yr}\left(\mathrm{r}^{2}=\right.$ $0.36)$ for the FW AU (Table A3), $-33.2 \pm 4.5$ acres $/ \mathrm{yr}\left(\mathrm{r}^{2}=0.64\right)$ for the HIMA AU (Table A4), $-23.0 \pm 2.6$ acres $/ \mathrm{yr}\left(\mathrm{r}^{2}=0.72\right)$ for the IA AU (Table A5), and $-8.2 \pm 0.9$ acres/yr $\left(\mathrm{r}^{2}=0.71\right)$ for the MRGO DMP AU (Table A6). The moderate to high $\mathrm{r}^{2}$ values indicate that loss has been relatively constant with time over the past 27 years within the MRGO DMP, HIMA, BBN, and IA AUs. The lower $\mathrm{r}^{2}$ value for the FW AU indicates that loss has not increased consistently with time over the 1983 to 2010 period. The other AUs, with the exception of the MRGO DMP AU, contain brackish marsh areas that are incurring slow loss with time. The MRGO DMP AU contains a narrow strip of the MRGO channel that has consistently widened over the past 25 years, providing a consistent loss rate with time. The FW AU consists of the 1935 forest area that converted to brackish marsh and often appears as a "wet" area on TM imagery, particularly after weather frontal passages with significant rainfall. Other images may record a "dry" condition, increasing land area. The oscillation between wet and dry images results in short-term land area variation with no clear trend with time.

Detailed land loss information for each AU can be found in Figures A3-A11.

\section{Episodic Impacts}

Historical 1935 to 1958 loss for the CWU was 2,688 acres and accounts for $40 \%$ of total loss from 1935 to 2010 (Table 2) suggesting formation by an episodic event. The 1.5 - $\mathrm{km}$ to 5 -km elongate orthogonal staggered ponds that cover the majority of the HIMA AU and the northern half of the MRGO DMP AU are typical of hurricane surge-formed features (Barras 2006, 2007; Barras et al. 2010; Figure A3). The only hurricane directly impacting the CWU area between 1935 and 1958 was the Fort Lauderdale 1947 Hurricane. 1940 Agricultural Commodity Service panchromatic aerial photography and 1952 USGS photography were used to constrain the formation of the ponds in the HIMA AU to this storm. The Category 1 hurricane followed a southeast-northwest track directly across Lake Borgne and into Lake Pontchartrain through the current Bayou Sauvage National Wildlife Refuge. The CWU was located in the storm's NE quadrant as it advanced across St. Bernard Parish. The O’Neal 1949 marsh type data identifies CWU marsh as fresh bordered by brackish three-cornered grass marsh adjacent to Lake Borgne. Based on observations conducted during recent hurricane studies, fresh marshes with high organic content are susceptible to compression and removal by hurricane surge (Barras 2006, 
2007; Barras et al. 2010; Howe et al. 2010; Morton and Barras 2011). The surge-impact features from this storm extend well past the CWU and are identifiable from northeastern Bayou Terre Aux Boeufs to the North Shore Marsh. Portions of these storm-formed ponds were truncated and filled in by dredged material placement within the MRGO DMP AU during the 19581965 period (Figure A4). Hurricane Hilda (October 3, 1964), a category 3 storm, passed to the west of the CWU after making landfall near Marone Point, Louisiana, but does not appear to have caused land loss in the CWU.

The $1965-1978$ net loss for the CWU is 1,864 acres or $28 \%$ of total net loss. Several major storms impacted the CWU during this period. The track of one storm, Hurricane Betsy (1965), was from southeast to northwest and was located south of the CWU, placing the CWU within the storm's northeastern quadrant. Hurricane Betsy was the most powerful storm to impact the CWU during this period and produced extensive surge flooding in eastern New Orleans. Visual review of aerial photography acquired four days after Betsy's landfall showed extensive flooding in the IA AU of formerly drained impoundments located east of the 40 Arpent Canal. Review of subsequent aerial photography showed that these impoundments remained flooded through 1969. A majority of the loss during the 1965-1978 period was likely related to this flooding (Figures A5, A14, and A19). Hurricane Betsy also caused some expansion of existing ponds within the HIMA SA and formed several new small scour ponds west of Bayou Dupre (Figure A5). Four years later, Hurricane Camille (August 17, 1969), a category 5 storm, passed to the east of the CWU resulting in minimal land loss in the CWU.

Net loss during the 1978 to 2004 period (Figures A6 - A8; Table 2) was 1,203 acres over a 26 -year period, and accounts for $18 \%$ of the total loss from 1935 to 2010. From 2004 to 2006 (October 26, 2006), 965 acres of episodic loss were directly attributable to Hurricane Katrina (Figure A9; Table 2). The Hurricane Katrina-induced loss was approximately $50 \%$ of the 26 years (1978 to 2004) of previous loss that occurred during a period of minimal hurricane impacts. Hurricane Katrina's surge flooded the CWU and caused expansion of ponds within the HIMA and IA AUs (Figure A.1.9). Additionally, Hurricane Katrina enlarged the small ponds previously formed by Hurricane Betsy near Bayou Dupre. Overall, the surge-induced losses within the CWU were minor compared to Hurricane Katrina's impacts near Delacroix, Alligator Point, and the North Shore Marsh (Barras 2006, 2007). Although both Hurricanes Betsy and Katrina caused 
observable impacts, neither storm's impacts within the CWU were as great as those of the 1947 Fort Lauderdale Hurricane. No significant land change within the CWU was observed during the 2006-2010 period of analysis although Hurricane Gustav (September 1, 2008), a category 2 storm, passed to the south of the area (Figure A10).

Total hurricane-induced loss within the CWU can be estimated by adding the 1935-1958 net loss, the 1965-1978 net loss, and the 2004-2006 net loss. The total net loss for these periods was 5,518 acres or $82 \%$ of total 1935-2010 net loss for the CWU (Table 2). Of the 5,159 acres lost between 1935 and 1978, 650 acres were lost from within the MRGO DMP AU, 2,242 acres from the HIMA AU, 475 acres from BBN AU, 109 acres from FW AU, and 1,683 acres from within the IA AU (Table 3). The actual direct loss contribution from the cumulative hurricane impacts was likely lower but was still conservatively above 50\%. Approximately 1,000 acres of Hurricane Betsy's loss was caused by flooding of formerly drained impoundments within the IA AU and does not reflect direct stormremoved wetland loss (Figure A5). The 1947 Fort Lauderdale Hurricane caused direct removal and compression of marsh within the HIMA and IA AUs (Figure A4). The BBN did contain some minimal surge-removed marsh from the 1947 Fort Lauderdale Hurricane but these ponds were filled, likely by dredged material placement, by 1965 (Figure A4). At least $60 \%$ of the net loss within the HIMA AU was caused by a storm that made landfall 63 years ago. The storm-formed features remained in place and retained their original shape for over a half century.

Table 3. Central Wetlands Assessment Units Land Area Trends by Period.

\begin{tabular}{|l|l|l|l|l|l|l|}
\hline & \multicolumn{7}{|c|}{ Land Change (Acres) } \\
\cline { 2 - 7 } & $\begin{array}{l}\text { MRGO Dredged } \\
\text { Material } \\
\text { Placement Area }\end{array}$ & $\begin{array}{l}\text { Hurricane } \\
\text { Impact and } \\
\text { Marsh Area }\end{array}$ & $\begin{array}{l}\text { Bayou } \\
\text { Bienvenue } \\
\text { North }\end{array}$ & $\begin{array}{l}\text { Forested } \\
\text { Wetlands }\end{array}$ & $\begin{array}{l}\text { Impoundment } \\
\text { Area }\end{array}$ & $\begin{array}{l}\text { Central } \\
\text { Wetlands } \\
\text { Unit }\end{array}$ \\
\hline $1935-1958$ & $-1,032$ & $-1,363$ & -208 & -30 & -55 & $-2,688$ \\
\hline $1958-1965$ & 744 & -345 & -218 & -151 & -637 & -606 \\
\hline $1965-1978$ & -361 & -534 & -50 & 72 & -992 & $-1,865$ \\
\hline $1978-1990$ & 35 & 170 & -76 & -175 & -375 & -421 \\
\hline $1990-2001$ & -52 & -265 & -89 & -13 & -146 & -565 \\
\hline $2001-2004$ & -152 & 33 & -9 & -43 & -46 & -217 \\
\hline $2004-2006$ & 6 & -386 & -44 & -335 & -206 & -965 \\
\hline $2006-2010$ & 7 & 376 & 2 & 170 & 83 & 638 \\
\hline Total & -805 & $-2,314$ & -691 & -505 & $-2,373$ & $-6,688$ \\
\hline
\end{tabular}




\section{Forested Wetland Area Change}

Rapid loss of forested wetland habitat occurred within the CWU throughout the 1935 to 1974 analysis period (both pre- and post-MRGO construction). In 1935, 44\% (13,924 acres) of the CWU consisted of forested wetlands (Table A7). Sixty-six percent (9,110 acres) of this habitat was located within the FW AU. The remaining CWU AUs contained 2,305 acres (17\%), 1,373 acres (10\%), 995 acres (7\%), 141 acres (1\%) for the AI, BBN, MRGO DMP, and HIMA AUs, respectively. Examination of the 1949 marsh type data (O'Neil 1949) shows that the CWU area delineated as forested wetland in 1935 was bordered on the east by a narrow strip of fresh marsh that was bounded in turn by a brackish three-corner grass marsh. This habitat gradient is typical of an abandoned Mississippi River distributary. However, by 1956 the majority of the forested wetland area near this fresh and nonfresh transition zone converted to fresh marsh (Wicker 1980; Figure A15). This habitat conversion accounted for the majority of the 25\% (3,420 acres) decline in CWU forested wetland habitat between 1935 and 1956.

Figure A12 illustrates this conversion, where 2,554 acres and 408 acres of the forested wetlands within the FW and MRGO AUs, respectively, converted to fresh marsh. Other secondary factors contributing to the loss of forested wetlands habitat from 1935 to 1956 include urban development (contributing to 256 acres lost from the IA AU) and construction of the GIWW canal (contributing to 233 acres lost from the BBN AU). Finally, the HIMA AU, which accounted for the smallest area of forested wetlands in 1935, experienced an increase of 29 acres of forested habitat by 1956.

Forested wetland area continued to decline during the 1956 to 1965 time period (Table A7). By 1965, an additional 3,812 acres of forested wetland, or $36 \%$ of the 1956 forested wetland area, were lost (Figure A13). The majority of the forested wetland lost between 1956 and 1965 occurred within the IA AU, accounting for $38 \%$ (1,433 acres) of the total loss for that time period. Primary causes include forest removal and conversion of impoundments to open water. In the FW AU, forested wetlands decreased by 1,039 acres during this period, primarily through habitat conversion to brackish marsh. This is confirmed by the 1968 marsh type data (Chabreck et al. 1968), which shows a rapid conversion of fresh to brackish marsh throughout the CWU marsh area. The conversion is possibly due to the increased salinities associated with MRGO construction. Other causes of forested habitat loss in this AU were commercial development, forest removal, as well as MRGO construction and dredged material placement (Figure A13). The rapid decrease in the extent of BBN AU forested wetland between 1956 and 1965 
(852 acres) was due to the expansion of the GIWW, the removal of forested wetlands for dredged material placement, and commercial development along the IHNC. Additionally, dredged material was placed within the MRGO DMP AU during this period, resulting in the removal of 520 acres of forested wetlands. Similar to the previous assessment period, the HIMA AU gained approximately 30 acres of forested wetlands during the 1956 to 1965 period.

Net loss of forested wetlands during the 1965 to 1974 period was 6,692 acres (Table A7). This loss, which signifies a complete conversion of forested wetlands within the CWU to brackish marsh, water, dredged material, or impoundments, encompasses the 9-year time frame following the MRGO construction (Figure A14). The majority of forested wetlands lost during the 1965 to 1974 period occurred in the FW AU (5,518 acres, or 83\%). By 1978, this AU was converted almost entirely to a brackish marsh and water landscape (Figure A16). Also during this period the 616 acres of forested wetlands within the IA AU were converted to open water. This loss was largely due to flooding from levee failures during Hurricane Betsy, causing the flooding of approximately 1,000 acres of impoundments within the IA AU (Figure A19). Hurricane Betsy also contributed, along with commercial development near the convergence of the IHNC and GIWW, to the removal of 289 acres of forested wetland habitat from the BBN AU. Following several decades of forest wetland gains, the HIMA AU experienced complete loss of all 202 acres of forested wetlands. Dredged material placement along the back flood protection levee of the southern MRGO DMP AU replaced the 67 acres of forested wetlands between 1965 and 1974. Though no forested wetlands were present in the CWU in 1974, a small pocket of cypress forest (86 acres) appeared to regenerate in the FW AU (near the Meraux pump station and back protection levee) in 1988 (Figure A17). 


\section{Conclusions}

The primary events affecting historical landscape change within the CWU over the past 75 years are linked to (1) cumulative hurricane impacts causing physical removal of marsh, (2) partial flooding of the IA AU after Hurricane Betsy, (3) construction of the MRGO causing habitat conversion, particularly loss of forested wetlands to brackish marsh or water, and (4) continuation of background processes causing continued loss with time.

Overall, examination of spatial land loss trends from 1935 through 2010 shows that the MRGO CWU is located in a relatively stable land loss area of the deltaic plain, lacking the larger land loss hotspots typifying the deltaic plain within the Barataria, Terrebonne, and Mississippi River Delta basins. The majority of land loss observed in the CWU occurred within the 1935-1958, 1965-1978, and 2004-2006 time periods, and the HIMA and IA assessment units. These time periods and assessment units accounted for $82 \%$ (based on time periods) and 70\% (based on assessment units) of the 1935-2010 CWU net loss, respectively. These losses are primarily due to MRGO-related dredging, impoundment development and flooding, and episodic impacts from hurricanes.

The 1947 Fort Lauderdale Hurricane, which caused the majority of the hurricane-induced loss within the CWU, accounted for $40 \%$ of the total 1935 to 2010 land loss. Eighteen years later, Hurricane Betsy flooded impoundments within the IA AU and partially expanded ponds that were previously created by the Hurricane of 1947 . Hurricane Katrina provided additional landscape changes, expanding ponds formed by previous hurricanes, and other water features. Total net loss for time periods containing episodic events comprised $82 \%$ of the CWU's net loss over the past 75 years. It is likely that a conservative $50 \%$ of CWU loss over the past 75 years is linked to these cumulative episodic impacts and non-linear events.

Rapid habitat conversion of forested wetland to marsh was likely accelerated by the construction of the MRGO. Fresh marsh occurring within the CWU in 1956 had converted to brackish marsh by 1968 (Chabreck et al. 1968). Shifts in salinity regime contributed to a significant decrease in forested wetlands by 1965 , and total removal by 1974 . Additional causes of 
forested wetland loss over the 1935 to 1974 assessment period include commercial development, forest removal, MRGO construction and dredged material placement, and hurricane-related impoundments. Although the MRGO-related dredging caused land loss in the CWU, the placement of dredged material also resulted in land gains in the Bayou Bienvenue North and MRGO Dredged Material Placement AUs between 1935 and 1965. The land gain may have resulted in the regeneration of forested wetlands in these AUs as noted by the evaluation of recent (2008) aerial photography.

The 1983 to 2010 assessment period represents relatively stable conditions with consistent loss rates within the CWU. This is demonstrated by the moderate to high $\mathrm{r}^{2}$ values, which indicates land loss was relatively constant within the MRGO DMP, HIMA, BBN, and IA AUs. Conversely, the FW AU demonstrated an $\mathrm{r}^{2}$ value indicative of land loss that did not increase consistently with time. This is evident in the habitat figures (Figures A15 - A18), which show that the FW AU landscape was dominated more by habitat switching than habitat loss. Loss projection rates based on the 1983 to 2010 time period should be reliable for shortterm projections. 


\section{References}

Barras, J., S. Beville, D. Britsch, S. Hartley, S. Hawes, J. Johnston, P. Kemp, Q. Kinler, A. Martucci, J. Port- house, D. Reed, K. Roy, S. Sapkota, and J. Suhayda. 2003. Historical and projected coastal Louisiana land changes 1978-2050, Appendix B of Louisiana Coastal Area (LCA), Louisiana Ecosystem Restoration Study. U.S. Geological Survey Open-File Report 2003-334, available online at http://pubs.er.usgs.gov/usgspubs/ofr/ofr03334.

Barras, J. A. 2006. Land area change in coastal Louisiana after the 2005 hurricanes-a series of three maps. U.S. Geological Survey Open-File Report 2006-1274, available online at http://pubs.usgs.gov/of/2006/1274/.

Barras, J. A. 2007. Satellite images and aerial photographs of the effects of Hurricanes Katrina and Rita on coastal Louisiana. U.S. Geological Survey Data Series 281, available online at http://pubs.usgs.gov/ds/2007/281.

Barras, J. A. 2009. Land area change and overview of major hurricane impacts in coastal Louisiana, 2004-08. U.S. Geological Survey Scientific Investigations Map 3080, scale 1:250,000. Available online at http://pubs.usgs.gov/sim/3080.

Barras, J. A., J. C. Bernier, and R. A. Morton. 2008. Land area change in coastal Louisiana-A multidecadal perspective from 1956 to 2006. U.S. Geological Survey Scientific Investigations Map 3019, scale 1:250,000, available online at http://pubs.usgs.gov/sim/3019.

Barras, J. A., J. C. Brock, R. A. Morton, and L. J. Travers. 2010. Remotely sensed imagery revealing the effects of Hurricanes Gustav and Ike on coastal Louisiana, 2008. U.S. Geological Survey Data Series 566,1 CD-ROM.

Barras, J. A., P. E. Bourgeois, and L. R. Handley. 1994. Land loss in coastal Louisiana 1956-90: National Biological Survey. National Wetlands Research Center OpenFile Report 94-01.

Chabreck, R. H., A. W. Palmisano, Jr., and T. Joanen. 1968. Vegetative type map of Louisiana coastal marshes. Baton Rouge, LA: Department of Wildlife and Fisheries.

Cowardin, L. M., V. Carter, F. C. Golet, and E. T. LaRoe. 1979. Classification of wetlands and deepwater habitats of the United States. Washington, DC: U.S. Gov't. Printing Office.

Howe, N., D. Fitzgerald, Z. Hughes, I. Georgiou, M. Kulp, M. Miner, J. Smith, and J. Barras. 2010. Hurricane-induced failure of low salinity wetlands. In Proceedings of the National Academy of Sciences of the United States of America 107(32):14014-14019. Available online at http://www.pnas.org/content/107/32/14014.full.

Louisiana Department of Natural Resources. 1992. Annual Monitoring Report - Violet Siphon Diversion - PO1. Baton Rouge, LA: Louisiana Department of Natural Resources. DNR Project No. 25030-91-30. 
Morton, R., and J. Barras. 2011. Hurricane impacts on coastal wetlands: A half-century record of storm-generated features from southern Louisiana. Journal of Coastal Research 27(6A):27-43.

Morton, R., J. Bernier, J. Barras, and N. Fernia. 2005. Rapid subsidence and historical wetland loss in the Mississippi Delta Plain, likely causes and future implications. U.S. Geological Survey Open-File Report 2005-1216. Available online at http://pubs.usgs.gov/of/2005/1216/.

O’Neil, T. 1949. The muskrat in Louisiana coastal marshes. New Orleans, LA: Wildlife and Fisheries Commission.

U.S. Geological Survey. 1951. Digital Raster Graphic (DRG) - Chalmette, Martello Castle, New Orleans East, Little Woods, and Delacriox Quadrangles. Reston, VA: U.S. Geological Survey.

Wicker, K. M. 1980. Mississippi Delta Plain Region Ecological Characterization: A habitat mapping study: A user's guide to the habitat maps. U.S. Fish and Wildlife Service, Office of Biological Services. FWS/OBS - 79/07.

http://www.gomr.boemre.gov/PI/PDFImages/ESPIS/3/4036.pdf 


\section{Appendix A}

Table A1. Central Wetlands Unit Net Land Area and Change Trends.

\begin{tabular}{|c|c|c|c|c|c|c|c|}
\hline \multicolumn{8}{|c|}{ Central Wetlonds Units } \\
\hline Date & Julian & Data & $\begin{array}{l}\text { Land } \\
\text { Area } \\
\text { (acres) }\end{array}$ & $\begin{array}{l}\text { Water } \\
\text { (acres) }\end{array}$ & $\begin{array}{c}\text { Total } \\
\text { (acres) }\end{array}$ & Land & water \\
\hline 1995 & 1925.0 & bes & $20,734.5$ & $1.140,4$ & $31,074,9$ & 96.45 & $2.6 \%$ \\
\hline 3935 & 10sao & Tobin pan & 20.046 .3 & $3,630,6$ & $31,474,9$ & an. 04 & 12.00 \\
\hline 1/31/10ss & t905.1 & Totin pan & $27,440)$. & $4,434.6$ & $31,874.9$ & a6.15 & 22.96 \\
\hline$\$ / 25 / 1974$ & 1974.8 & $\mathrm{can}$ & $24,060,4$ & 7,000 s & $31,874,9$ & $75.5 \%$ & 24.54 \\
\hline $1 / 6 / 1983$ & 1983.0 & $T M$ & $26,115,2$ & $5,759.8$ & $31,874.9$ & 81.99 & $18,1 \%$ \\
\hline $9 / 29 / 1984$ & $\$ 984,7$ & $T \mathrm{M}$ & $26,402.6$ & $6,472.1$ & $31,074,9$ & 39,70 & 20.346 \\
\hline 1/19/1985 & 1985.1 & $\mathrm{TM}$ & $25,970.8$ & $5,504.2$ & $31,874,9$ & $81.5 \%$ & $18,5 \%$ \\
\hline M/O1/19as & 19as.7 & $\mathrm{TM}$ & 25.174 .9 & $6,700.1$ & $31,474,9$ & 79.04 & 21.05 \\
\hline $3 / 27 / 1985$ & 1986.2 & $\mathrm{TM}$ & $25,818.2$ & $6,056.8$ & $31,874,9$ & $81.0 \%$ & $12.0 \%$ \\
\hline $10 / 2 / 1907$ & 2907.8 & $T M$ & $25,715.0$ & $6,259,9$ & $31,874,9$ & 00,75 & 39.34 \\
\hline 11/1/19\% & 1990.8 & $\mathrm{TM}$ & $25,154.6$ & $6,720,4$ & $31,874.9$ & 78.95 & $21.1 \%$ \\
\hline $10 / 11 / 1991$ & t991:s & $\mathrm{TM}$ & $24,565.2$ & $7,309.6$ & $31,074,9$ & 77.16 & 22.946 \\
\hline $10 / 5 / 1992$ & 1992.8 & $T M$ & $24,534,4$ & $7,340.5$ & $31,874,9$ & 77.05 & 23.04 \\
\hline $2 / 37 / 3904$ & 1994.2 & $\mathrm{TM}$ & $25,349,0$ & $6,525.7$ & $21,474,9$ & $79.5 \mathrm{t}$ & 20.514 \\
\hline $11 / 15 / 1995$ & 1995.9 & $\mathrm{TM}$ & $24,786.1$ & $7,068.7$ & $31,674,9$ & 77.85 & 22.24 \\
\hline $4 / 7$ isis & 1996.3 & $T M$ & $24,677.2$ & 7, 1997,8 & 31.874 .9 & 77.46 & 22.64 \\
\hline $10 / 3 / 1997$ & 1997.8 & $\mathrm{TM}$ & $25,025,3$ & $6,849.6$ & $31,874.9$ & 78.55 & $21.5 \%$ \\
\hline $2 / 24 / 1996$ & 1990.2 & $\mathrm{TM}$ & $25,264.7$ & $6,610.2$ & $31,474,9$ & 79.26 & 20.74 \\
\hline $11 / 19 / 199$ & 1999.9 & $T M$ & $24,563,2$ & $7,311.7$ & $31,874.9$ & 77.15 & 22.946 \\
\hline $10 / 11 / 2000$ & 2000.6 & $\mathrm{TM}$ & $24,164,5$ & $7,710.5$ & $31,474,9$ & 75.46 & 24.24 \\
\hline $10 / 30 / 2001$ & 2001.8 & $\mathrm{TM}$ & $24,589.5$ & $7,285.4$ & $31,874.9$ & 77.196 & $22.9 \%$ \\
\hline $2 / 27 / 2002$ & 2002.2 & $7 M$ & $25,192.9$ & $6,650,1$ & $31,074,9$ & 79.05 & 21.06 \\
\hline $12 / 28 / 2002$ & 2003.0 & $\mathrm{TM}$ & $24,497,3$ & $3,377,7$ & $31,874,9$ & $76.8 \%$ & $23,1 \%$ \\
\hline $10 / 20 / 2007$ & 2003.0 & $\mathrm{TM}$ & $24,514,1$ & $7,200.0$ & $31,074,9$ & 20.84 & 22.16 \\
\hline $11 / 2 / 2004$ & 2004.9 & $\mathrm{TM}$ & $24,373.0$ & $7,501.9$ & $31,874,9$ & $76.5 \%$ & $23.5 \%$ \\
\hline $10 / 9 / 2005$ & 2005.8 & $T M$ & $22,701.3$ & $9,173,6$ & $31,074,9$ & 7126 & 20.00 \\
\hline $10 / 25 / 2005$ & 2005.8 & $\mathrm{TM}$ & $23,616.4$ & $8,258.5$ & $31,874.9$ & 74.15 & $25.9 \%$ \\
\hline $9 / 20 / 2006$ & 2006.7 & $\mathrm{TM}$ & 22.541 .0 & 9.236 .9 & $31,074,9$ & 90.70 & 29.34 \\
\hline $10 / 23 / 2006$ & 2006.8 & $T M$ & $23,408,2$ & $8,456.18$ & $31,874,9$ & $72 .+6$ & $26,6 \%$ \\
\hline $2 / 7 / 3007$ & 2007.2 & $\mathrm{TM}$ & $24,297,1$ & $7,577,8$ & $31,474,9$ & 76.246 & 23.016 \\
\hline $4 / 6 / 2007$ & 2007.3 & $\mathrm{TM}$ & $23,224.6$ & $8,650.2$ & $31,674,9$ & 72.95 & 27.146 \\
\hline 10rivions & 2008.5 & $T M$ & n.559.5 & 6.,75:.4 & 31.574 .9 & $n .6$ & 36.14 \\
\hline $11 / 2 / 2006$ & 2000.6 & $\mathrm{TM}$ & 22.037 .2 & $0,097,7$ & $31,474,9$ & 74.56 & 25.24 \\
\hline $9 / 2 / 2000$ & 2009,7 & $\mathrm{TM}$ & $23,805.2$ & $8,069.8$ & $31,874.9$ & 74.796 & $25,3 \%$ \\
\hline $2 / 21 / 2010$ & 2010.2 & $\mathrm{TM}$ & $24,046.3$ & $7,028,7$ & $31,674,9$ & $78.4 \mathrm{~V}$ & $24.6 \mathrm{~s}$ \\
\hline
\end{tabular}

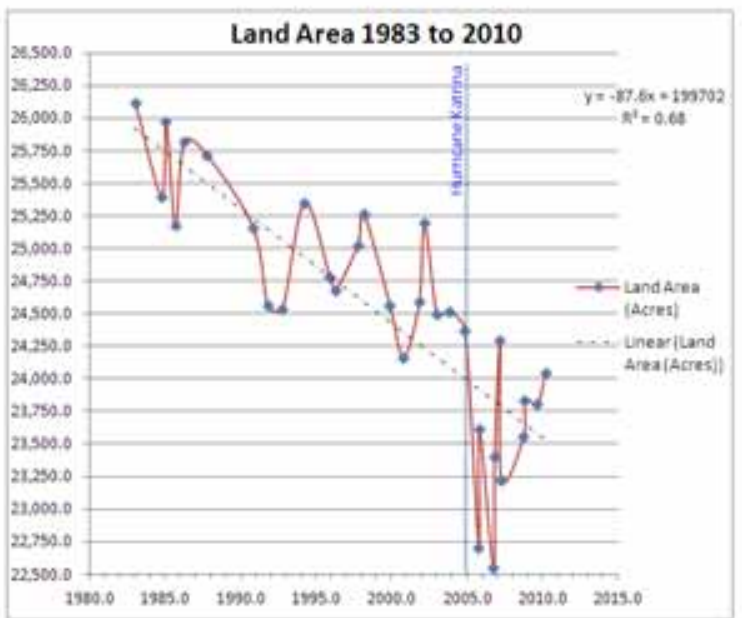

Slope or trend $=-87.6=11.1$ acres/yr from 1983 to 2010 क $95 \%$ confidence ntervat. Simple inear regression calculated using Prosm statistics software.

\begin{tabular}{|c|c|c|c|c|}
\hline \multicolumn{5}{|c|}{ HetLand Change by Time Period, } \\
\hline the & herval & $\begin{array}{l}\text { Chanos } \\
\text { (acress) }\end{array}$ & $\begin{array}{l}\text { Penod } \\
\text { (yeara) }\end{array}$ & 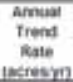 \\
\hline enal-senta & 1 1925-1959 & .26892 & 230 & -1169 \\
\hline Aarrial-Aeria & 1 1950-195s & -6050 & 71 & $-95 \mathrm{a}$ \\
\hline enal- Mat & t965-1972 & -1.364 .5 & 13.7 & -136.2 \\
\hline \multicolumn{5}{|c|}{ 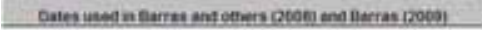 } \\
\hline ab-TM & $1976-1990$ & -4212 & 120 & 350 \\
\hline 1. TM & $1990-2001$ & .5651 & 110 & $-5+2$ \\
\hline TM: TM & $2001 \cdot 2004$ & -216.5 & 3.0 & -71.2 \\
\hline A.TM & $2004-2006$ & -9648 & 20 & +499 1 \\
\hline 1.TM & $2006-2000$ & 151.3 & 1.8 & 70.5 \\
\hline Lenal- TM & $1935-2010$ & -6.608 .2 & 75.2 & -88.9 \\
\hline \multicolumn{5}{|c|}{ Inmadere 2005 thricanes } \\
\hline & $2004 * 200$ & -756.5 & 0.86 & He \\
\hline
\end{tabular}

Datareferencet:

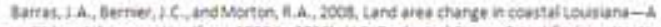

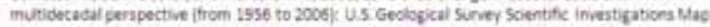

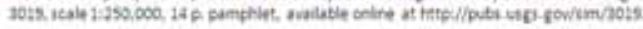

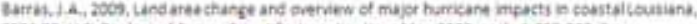

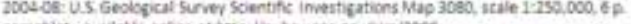

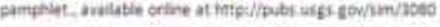

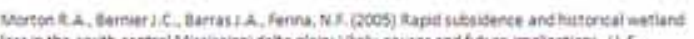

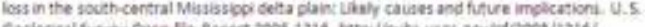

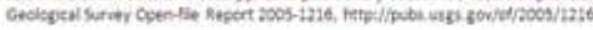

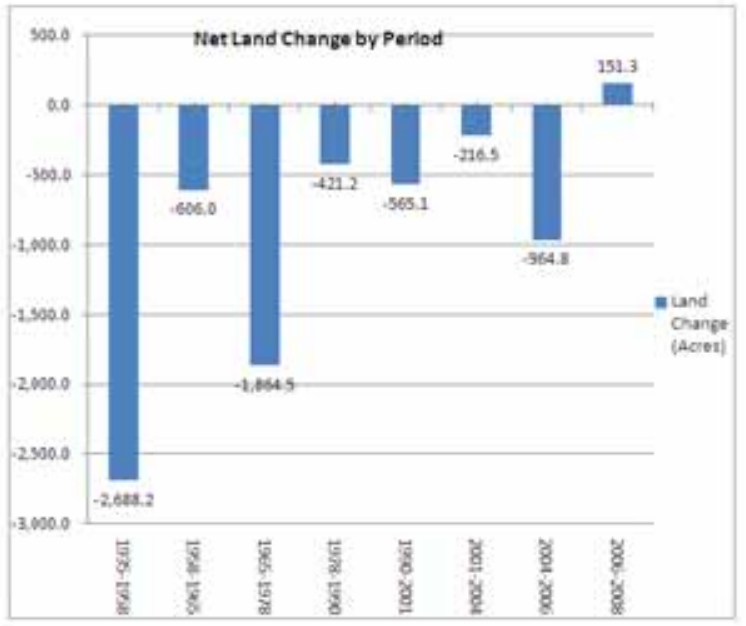


Table A2. Central Wetlands Unit - Bayou Bienvenue North Assessment Unit Area and Change Trends.

\begin{tabular}{|c|c|c|c|c|c|c|c|}
\hline \multicolumn{8}{|c|}{ Central Wetlands - bayou Blenvenuet North Area Trends } \\
\hline Date & Julian & Data & $\begin{array}{l}\text { Land } \\
\text { Arsed } \\
\text { (acress) }\end{array}$ & $\begin{array}{c}\text { Water } \\
\text { (acres) }\end{array}$ & $\begin{array}{c}\text { Total } \\
\text { (acres) }\end{array}$ & $\begin{array}{c}\% \\
\text { Land }\end{array}$ & $\begin{array}{c}\text { \%o } \\
\text { Water }\end{array}$ \\
\hline 1935 & t9as:0 & $\cos$ & 2490.0 & 102.9 & 2593.7 & 97.14 & $2.9 \%$ \\
\hline 1958. & 1958.6 & Tobin Parf & 3283.1 & 310.6 & 3593.7 & 91.66 & B.65 \\
\hline $1 / 31 / 1965$ & t9os: 1 & Tobin Part & 3065.3 & s2a.3 & 3593.7 & 85.346 & 14,75 \\
\hline $9 / 15 / 1974$ & 1974.8 & CIR & 2951.7 & 642.0 & 3593.7 & $62.1 \%$ & $17.9 \mathrm{~m}$ \\
\hline $1 / 6 / 1983$ & 1983.0 & $\mathrm{TM}$ & 3017.0 & 576.7 & 3593.7 & 84.05 & 26,096 \\
\hline $4 / 6 / 1904$ & $19 \$ 4,3$ & $\mathrm{TM}$ & 3021.2 & 572.5 & 3593.7 & 54.15 & 15.95 \\
\hline $9 / 29 / 1904$ & 1964.7 & $T M$ & 2906.4 & 607.3 & 1593.7. & 63.16 & 15.96 \\
\hline 1/19/19as & t9as: 1 & $\mathrm{TM}$ & 3 & & & 83.466 & 16.05 \\
\hline e/31/19as & 5985.7 & $7 M$ & 1 & & & แ3..86 & 16.25 \\
\hline $2 / 27 / 19 a 6$ & Igas. 2 & & & & & a2.646 & $17.4 \%$ \\
\hline to/a/19a7. & tow: & & & & & 112.546 & 17,50 \\
\hline 1/2a/19as & 196s.1 & TMt & 0.3 & sas. 4 & 3593.7 & 13.646 & 16.48 \\
\hline $1 / 27 / 1909$ & t969.0 & Habitat & 30.9 & 622.4 & 3593.4 & 182.70 & $17.2 \mathrm{~s}$ \\
\hline $12 / 26 / 1909$ & 1990.0 & $T M$ & 205.3 & 600.3 & 2593.7 & 00.056 & 19.25 \\
\hline $11 / 1 / 1990$ & 1990,1 & $\pi$ & 9.5 & 654.2 & 2593.7 & ถ1. $2.6 \mathrm{~s}$ & $26.2 \mathrm{~s}$ \\
\hline $10 / 11 / 1991$ & 1991:8 & $\mathrm{TM}$ & 198.6 & 695.1 & 3593.7 & $00.7 \%$ & $19.3 \mathrm{~s}$ \\
\hline $10 / 5 / 1992$ & 1992.8 & $\mathrm{TM}$ & 198.2 & 695.4 & 3593.7 & B0.65 & 19,45 \\
\hline $1 / 25 / 1993$ & 1993.1 & $\mathrm{TM}$ & 9.1 & 744.6 & 3593.7 & 79.346 & 20.75 \\
\hline $3 / 17 / 1904$ & 1904.2 & $\mathrm{TM}$ & 201.0 & 602.7 & $35 \times 3.7$ & 80.746 & $19.3 \%$ \\
\hline $11 / 15 / 1995$ & 1995.9 & $T M$ & 2963.6 & 230.0 & 3593.7 & 70.76 & 20.35 \\
\hline $4 / 7 / 1996$ & 1996.3 & $\mathrm{TM}$ & 2892.8 & 700.9 & 3593.7 & $80.5 \%$ & $19.5 \%$ \\
\hline $10 / 3 / 1997$ & 1997.8 & $\mathrm{TM}$ & 2901.3 & 692.4 & 3593.7 & 80.796 & $19.3 \%$ \\
\hline $2 / 24 / 1998$ & 1998.2 & $T M$ & 88.4 & 705.3 & 3593.7 & 80.486 & $19.6 \%$ \\
\hline $11 / 18 / 1999$ & 1999,9 & $\mathrm{TM}$ & 63.0 & 730.7 & 3593,7 & 79.746 & $20.3 \%$ \\
\hline $10 / 11 / 2000$ & 200 & $\mathrm{TM}$ & & 742.7 & 3573.7 & 79.396 & 20.79 \\
\hline $10 / 30 / 2001$ & 20 & & & & & $70.3 \%$ & $20.7 \%$ \\
\hline & & & & & & 196 & $3 \%$ \\
\hline & & & & & & & \\
\hline tor & & & & -4 & & $79.6 \%$ & 20.45 \\
\hline $11 / 7 / 2004$ & 2004,9 & TH. & 2041.6 & 752.1 & 3503.7 & 79.16 & 20.90 \\
\hline to/g/zoos & 2005 .a & $\mathrm{TM}$ & 2723.4 & 370.3 & 3593.7 & 75.946 & 24,25 \\
\hline $40 / 25 / 2005$ & 2005.6 & $\mathrm{TM}$ & 2007.7 & 790.0 & 2593.7 & 20.16 & 21.90 \\
\hline $9 / 26 / 2006$ & 2006.7 & $\mathrm{TM}$ & 2760.3 & a3..4 & 3503.7 & 76.646 & 23.24 \\
\hline $50 / 22 / 2006$ & 2006.4 & $T M$ & 2797.4 & 796.6 & 3593.7 & 77.846 & 22.25 \\
\hline $3 / 7 / 2007$. & 2007.2 & $\mathrm{TM}$ & 2054.1 & 739.6 & 2503.7 & 79.446 & 20.45 \\
\hline $4 / 6 / 200 t$ & 2009.3 & $T M$ & 2009.0 & $7 a 4.7$ & 3593.7 & 78.26 & 21.04 \\
\hline to/1/200a & 200 at & $\mathrm{TM}$ & & 796.6 & 2593.7 & 77.846 & 22.25 \\
\hline $12 / 1 / 200 a$ & 2000,8 & $\pi$ & 2004,0 & 709.7 & 35 & $70.0 \%$ & $22.0 \mathrm{n}$ \\
\hline $9 / 2 / 2009$ & 2009.7 & $\pi$ & 2815.6 & 778.1 & 3593.7 & $70.3 \%$ & 21.75 \\
\hline $23 / 2010$ & 2010.2 & $7 \mathrm{M}$ & 2799.4 & 794.3 & 3693.7 & $77.9 \%$ & 22.1 \\
\hline
\end{tabular}

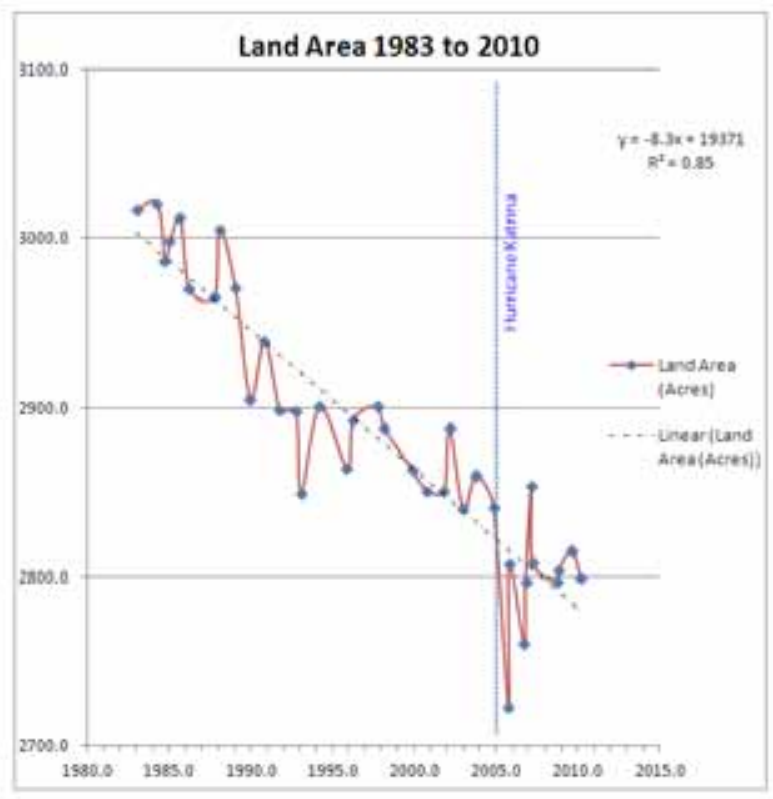

Slope or trend $=-8.3 \neq 0.6$ acres/yr from 1983 to 2010 e $95 \%$ confidence interval Simple Inear regression calculated using Prism statistics software.

\begin{tabular}{|c|c|c|c|c|}
\hline \multicolumn{5}{|c|}{ Het Land Change by Time Period } \\
\hline Thos & interva & $\begin{array}{l}\text { Chaspe } \\
\text { (esresi) }\end{array}$ & $\begin{array}{l}\text { Penod } \\
\text { getars! }\end{array}$ & $\begin{array}{c}\text { Amusi } \\
\text { Trend } \\
\text { Rate } \\
\text { (ecoresion }\end{array}$ \\
\hline Aeprial-Aeqrial & 1935.1959 & 8077 & 200 & 40 \\
\hline Aeral-Aense & $1958-1965$ & 217.8 & 71 & 307 \\
\hline Antial-neab & $1965: 1972$ & 495 & 137 & -36 \\
\hline \multicolumn{5}{|c|}{ 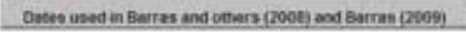 } \\
\hline Hate-TM & $1970-1960$ & -76.3 & 120 & 83 \\
\hline $7 M-T M$ & $1990-2001$ & -888 & 110 & 81 \\
\hline$T M-T M$ & $200 t-2004$ & 9.1 & 30 & 20 \\
\hline $\mathrm{TM}-\mathrm{TM}$ & $2004-2008$ & 45 & 20 & 226 \\
\hline M-TM & $2006-2009$ & 0.0 & 19 & 0.0 \\
\hline enal-TM & $1935-2010$ & 4914 & 732 & 92 \\
\hline \multicolumn{5}{|c|}{ immedate zoos iturikanes } \\
\hline M-TM & $2004-2005$ & 538 & 096 & 35.1 \\
\hline
\end{tabular}

Becareterences:

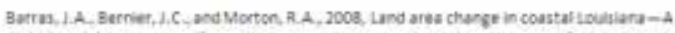

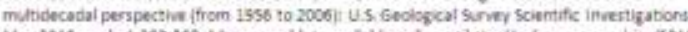

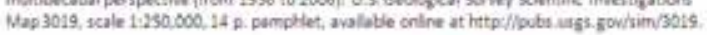

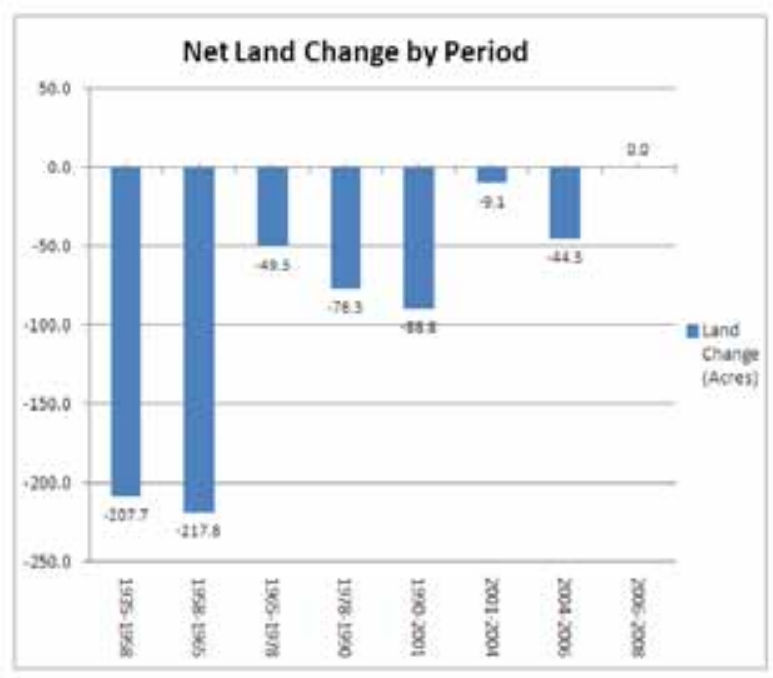

Barras, 1. A, 2005, Landareschange and overview of major hurricane irrescts n costal

Louslane, 2004-08: U.S Gedogcal surver scientent investigations Map 3000, stale 1:250,000, 6 
Table A3. Central Wetlands Unit - Forested Wetlands Assessment Unit Area and Change Trends.

\begin{tabular}{|c|c|c|c|c|c|c|c|}
\hline \multicolumn{8}{|c|}{ Central Wetlands - Forested Wetlands Mrea Trends } \\
\hline Date & Jutian & Data & $\begin{array}{c}\text { Land } \\
\text { Area } \\
\text { (acres) }\end{array}$ & $\begin{array}{l}\text { Water } \\
\text { (acres) }\end{array}$ & $\begin{array}{c}\text { Total } \\
\text { (acres) }\end{array}$ & $\begin{array}{l}\text { Who } \\
\text { Land }\end{array}$ & Water \\
\hline 19as & 1935.0 & once & $9: 47.4$ & 105.8 & 9253.2 & 90.96 & 1.16 \\
\hline 1958 & 1958.0 & Tobin Pan & 9117.0 & 136.2 & 9253.2 & 98.55 & $1.5 \%$ \\
\hline $2 / 31 / 1965$ & 1965.1 & Tobin Pan & aseb.2. & 287,0 & 9253.2 & 96.95 & 3.16 \\
\hline $9 / 15 / 1974$ & 1974.8 & CIR & 8222.6 & 1030.6 & 9253.2 & 88.95 & 11.196 \\
\hline $1 / 6 / 2902$ & 1902.0 & $\mathrm{TM}$ & a49, 7 & 342.5 & 9252.2 & 96.2n & $2.7 \%$ \\
\hline $4 / 6 / 3924$ & 1964.3 & & & & 9253.2 & $90.18 \mathrm{~s}$ & 1.26 \\
\hline $9 / 20 / 1984$ & 196. & & & & 3.2 & 94,14 & $5.9 \%$ \\
\hline 1/19/19as & & & & & & 95.uss & 4.246 \\
\hline a/31/t9as & & & & & 2.2 & 92.95 & 7.16 \\
\hline $1 / 27 / 1908$ & & & & .9 & 9253.2 & 99.3s & 1.70 \\
\hline $20 / 3 / 1987$ & $1987, \mathrm{G}$ & & 110.0 & 143.2 & 9253.2 & $96.5 \%$ & $1.5 \%$ \\
\hline $1 / 28 / 1988$ & 1988.1 & TMM & 8979.5 & 273.7 & 9253.2 & 97.05 & 3.096 \\
\hline $1 / 17 / 1989$ & 1989.0 & Habitat & 9213.4 & 39.8 & 9253.2 & $99.6 \mathrm{~s}$ & 0.456 \\
\hline $12 / 16 / 1939$ & 1990.0 & $T M$ & 8872,0 & 381.2 & จ253.2 & 95.95 & 4.156 \\
\hline $11 / 1 / 19 \%$ & 1990.8 & $\mathrm{TM}$ & 8883.5 & 389.7 & 0253.2 & 95.85 & 4.246 \\
\hline $10 / 11 / 1991$ & 1995. & $\mathrm{TM}$ & 8882.8 & 570.4 & 9253.2 & 93.6\% & 6.26 \\
\hline $10 / 5 / 3902$ & 1992.8 & $\mathrm{~mm}$ & 0666.2 & $\operatorname{san} .0$ & 9253.2 & 90.75 & 6.). 40 \\
\hline $3 / 17 / 1994$ & 1094.2 & $\mathrm{TM}$ & 9104.3 & $14 a .9$ & 9253.2 & 90.45 & $1.6 \%$ \\
\hline $12 / 15 / 1995$ & t99: & $T M$ & alas .9 & 304.3 & 9253.2 & 95.ans & 4.24 \\
\hline $4 / 7 / 1956$ & 199 & M & 0664,9 & saa.J & 9253.2 & 90.64 & 6.46 \\
\hline $10 / 2 / 1997$ & 199 & $m$ & 0 & 210.2 & 9253.2 & $97.6 \mathrm{~N}$ & 2.446 \\
\hline $2 / 24 / 1996$ & 199 & $\mathrm{TM}$ & 7 & $2+0.5$ & 9253.2 & 97,45 & $2.67 \%$ \\
\hline $11 / 18 / 19 \%$ & 1999.9 & $\mathrm{TM}$ & 374.7 & 378.5 & 9253.2 & $95.9 \%$ & 4.15 \\
\hline $10 / 11 / 2000$ & 2000.8 & $\mathrm{TM}$ & 6580.8 & 672.4 & 9253.2 & 92,75 & $7.3 \%$ \\
\hline $10 / 30 / 2001$ & 2002 a & $T M$ & 8850.6 & 402.6 & 9253.2 & 95.65 & .4 .496 \\
\hline $2 / 22 / 2002$ & 2002.2 & $\mathrm{TM}$ & $89+4.2$ & 309.0 & จ253.2 & 96,75 & 3.396 \\
\hline $12 / 28 / 2002$ & $2003 . a$ & $\mathrm{TM}$ & 8611.9 & 641:3 & 9253.2 & 93.15 & 6.956 \\
\hline $10 / 20 / 2002$ & 2002. & $\mathrm{TM}$ & 07 t).2 & 4as.: & 9252.2 & 24.an & S.2.ts \\
\hline $11 / 7 / 2004$ & 2004.9 & $m$ & asom.a & 445.4 & 9253.2 & 95.25 & 4.616 \\
\hline $20 / 9 / 2005$ & 2005.18 & $7 m$ & $\operatorname{ses} 2.6$ & 1220.6 & 9253.2 & a6.uns & 13.246 \\
\hline $10 / 25 / 2005$ & $2005 . \mathrm{A}$ & $\mathrm{TM}$ & 0344.2 & 909.0 & 9253.2 & 90.25 & 9.64 \\
\hline $9 / 26 / 2006$ & 2006 & $\mathrm{TM}$ & $\operatorname{ax} 7.4$ & 973.0 & 9253.2 & $69.5 \mathrm{~s}$ & 10.596 \\
\hline $10 / 21 / 2006$ & 2006 & $T M$ & 3473.1 & 780.1 & 9253.2 & 91.65 & 0.46 \\
\hline & 200 & & & 9 & 9253.2 & $93.8 \%$ & $6.2 \%$ \\
\hline $6 / 2007$ & 2001 & TाM & 843 & 617.5 & 9253.2 & 91.25 & 8.856 \\
\hline $10 / 1 / 2000$ & 2008 & $\pi$ & 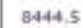 & 8087 & 9253.2 & 91.35 & $8.7 \%$ \\
\hline 21 & 200 & $1 \mathrm{~m}$ & & 0 & 9253.2 & 93.28 & $6.8 \%$ \\
\hline & & & & & 9253.2 & Q4.26 & $5.8 \%$ \\
\hline $2 / 25 / 2010$ & 20102 & $\mathrm{mM}$ & 0642.7 & 605 & 92532 & 93.45 & $0.6 \%$ \\
\hline
\end{tabular}

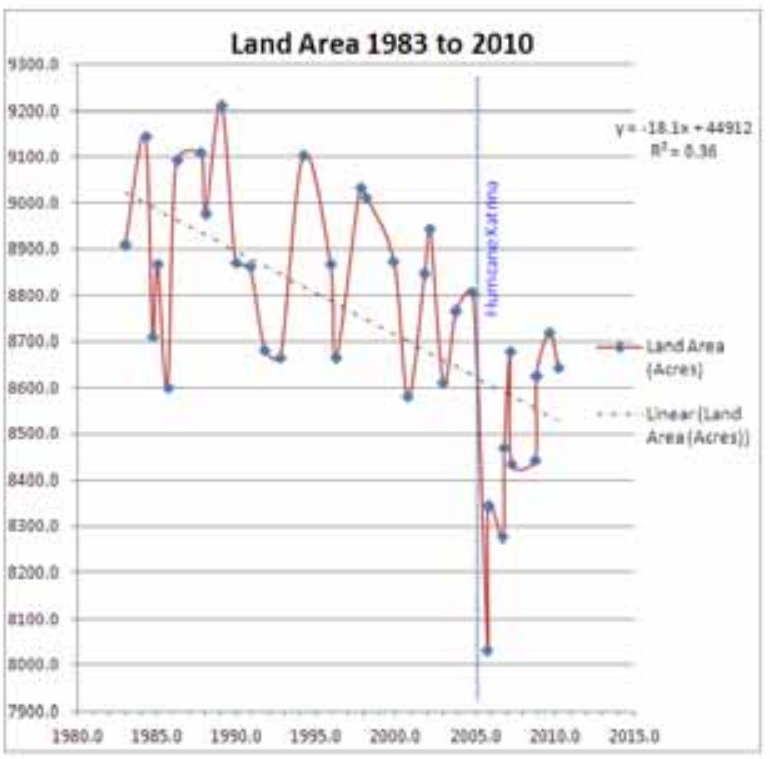

Slope or trend $=-18.1 \pm 4.2$ acres/yr from 1983 to 2010 o $95 \%$ confidence interval. Simple Inear regression calculated using Prism statistics software.

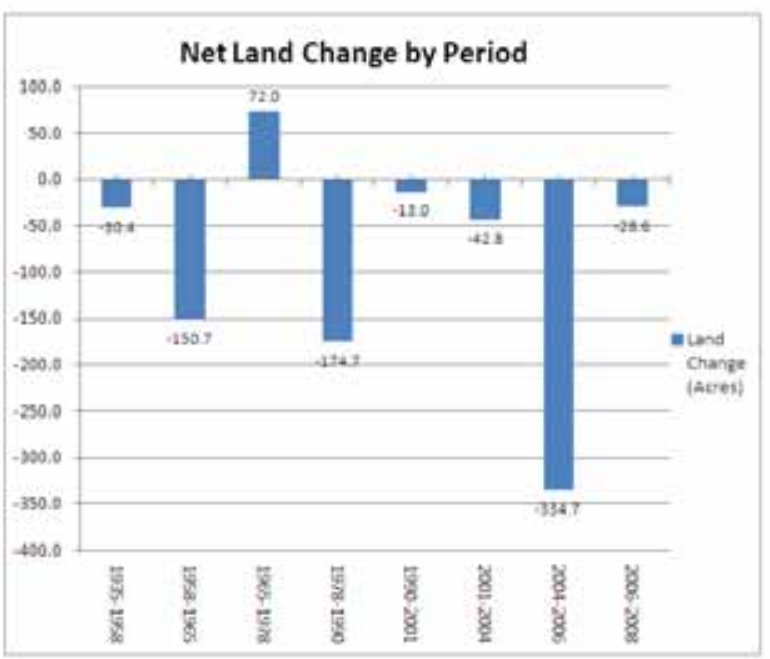

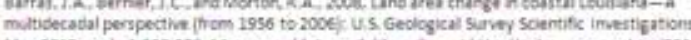

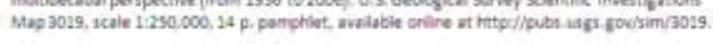

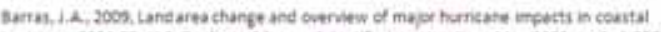

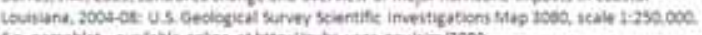

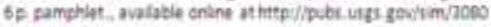

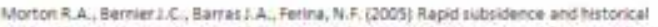

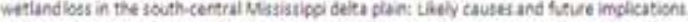

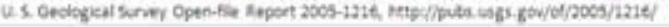


Table A4. Central Wetlands Unit - Hurricane Impact and Marsh Assessment Unit Area and Change Trends.

Central Wetlands - Murricane tmpact and Marsh Area Trends

\begin{tabular}{|c|c|c|c|c|c|c|c|}
\hline Date & tian & Bata & $\begin{array}{c}\text { Land } \\
\text { Area } \\
\text { (acres) }\end{array}$ & $\begin{array}{l}\text { Water } \\
\text { (acres) }\end{array}$ & $\begin{array}{c}\text { Total } \\
\text { (acres) }\end{array}$ & tand & $\begin{array}{c}\text { Wh } \\
\text { water }\end{array}$ \\
\hline t9as & 1925.0 & DAE & 0470.7 & 420,2 & to9s.9 & 95.25 & $4.0 \%$ \\
\hline 1958 & 1958.0 & Tobin pan & 7116.6 & 1793.2 & 6900,9 & 79.95 & $20.14 \mathrm{r}$ \\
\hline $1 / 3 t / 1955$ & 1965.1 & Tebin pan & 6722.1 & 2337.0 & apos.9 & 76.05 & $24.0 \%$ \\
\hline $9 / 15 / 1974$ & 1974.8 & 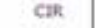 & 6125.1 & 2704.7 & 4909,9 & $\operatorname{sen} 74$ & $31.2 \mathrm{~s}$ \\
\hline $1 / 6 / 1983$ & 1983.0 & $T M$ & 6881.6 & 2028.3 & 9909,9 & 77.25 & $22.8 \%$ \\
\hline $9 / 29 / 1944$ & $19 \$ 4,7$ & $T M$ & 6592.6 & 2317.2 & 0909.9 & 74.05 & $26.0 \mathrm{~s}$ \\
\hline $1 / 19 / 2935$ & 1965.1 & $\mathrm{TM}$ & 0870.3 & 2030.6 & 3800,9 & 77.25 & $22.6 \%$ \\
\hline $8 / 31 / 1985$ & 1985.7 & TM & 6573.5 & 23364 & 8909.8 & $73.8 \%$ & $26.2 \%$ \\
\hline $3 / 27 / 1996$ & 1886.2 & $\mathrm{TM}$ & 65a7,6 & $2 m 2.3$ & 8609.9 & 75.16 & 24,96 \\
\hline $10 / 1 / 19957$ & 3987.4 & $\mathrm{mM}$ & 6557.7 & 2352.2 & topog.9. & 73.68 & $26.4 \%$ \\
\hline $12 / 16 / 1969$ & 1990.0 & $T M$ & 6502.4 & 2407.5 & 8909.9 & $73.0 \mathrm{~s}$ & $27.0 \%$ \\
\hline $11 / 1 / 1990$ & 199.8 & $T M$ & 508.1 & 2501.8 & 8909.9 & 71.95 & 26.14 \\
\hline $10 / 11 / 1941$ & 1991.8 & $T M$ & 6269.1 & $26+0.0$ & $\operatorname{apos:9}$ & 70.45 & $29.6 \%$ \\
\hline $10 / 5 / 1992$ & 1992.8 & TM & 6233.4 & 2576.5 & 8909,9 & 70.05 & $30.0 \%$ \\
\hline $1 / 25 / 1993$ & 1993.1 & TM & 6164.5 & 2745.3 & 9909.9 & 69.25 & $30.8 \%$ \\
\hline $3 / 17 / 1994$ & 1994.2 & TM & 6423.0 & 2486.4 & 9909.9 & 72.16 & 27.94 \\
\hline $11 / 15 / 1995$ & 1595,9 & TM & 6278.6 & 2631.2 & 9609,9 & 70.55 & $29.5 \%$ \\
\hline $4 / 7 / 1996$ & 1996.3 & $T M$ & 6356.8 & 2553,1 & 8909,9 & $713 \%$ & $28,7 \%$ \\
\hline $10 / 2 / 1997$ & 1957.8 & $T M$ & 6204,8 & 2625.0 & s409,9 & $70.5 \mathrm{~s}$ & $29.5 \mathrm{~s}$ \\
\hline $2 / 24 / 1998$ & 1908.2 & TM & 6529.6 & 2360.2 & 6909.9 & 735 & $26.74=$ \\
\hline $11 / 16 / 1999$ & 1999.9 & $T M$ & 6115.7 & 27942 & 8009,9 & 68.65 & 31,45 \\
\hline $10 / 11 / 2000$ & 2000.4 & TM & 6041.2 & 2068.6 & t909.9 & 67.05 & $32.2 \%$ \\
\hline $10 / 30 / 2001$ & 2001.0 & $\mathrm{TM}$ & $61+2.7$ & 2767.1 & .8909 .9 & $60.9 \mathrm{~s}$ & $31.1 \%$ \\
\hline $2 / 27 / 2002$ & 2002.2 & $T M$ & 6430.0 & 2479.9 & 6909.9 & 7225 & $27.8 \%$ \\
\hline $12 / 2 \mathrm{a} / 2002$ & 2002,0 & $T M$ & 6269.5 & 2620.4 & $\operatorname{ap} 09.9$ & 70.65 & $29.4 \mathrm{~s}$ \\
\hline $10 / 20 / 2003$ & 2003.2 & $T M$ & 6162.2 & 2747,7 & 9909.9 & 69.25 & $30.0 \mathrm{v}$ \\
\hline $11 / 7 / 2004$ & 2004,9 & TM & 6175.6 & 2734.2 & 8909.9 & 69.35 & 30.746 \\
\hline $10 / 9 / 2005$ & 2005.4 & $\mathrm{TM}$ & 5691.9 & 3217.9 & 4909.9. & 0.96 & 36.16 \\
\hline $10 / 2 \mathrm{~s} / 2005$ & 2005.8 & $\mathrm{TM}$ & 5960.8 & 2911.1 & apos.9. & 67.26 & 32.76 \\
\hline $9 / 26 / 2000$ & 2005.7 & TM & 5243.0 & 3665.9 & 8909.9 & $58.8 \%$ & $41.2 \%$ \\
\hline $10 / 211 / 2005$ & 2006.8 & TM & 5769.7 & 3120.2 & 5909.9 & 65.05 & $35.0 \%$ \\
\hline $2 / 7 / 2007$ & 2007.2 & $\mathrm{TM}$ & 6245.1 & 2664,7 & $\operatorname{arcos} .9$ & 70.16 & 29.96 \\
\hline $4 / 6 / 2007$ & 2007,3 & $T M$ & 5656.7 & 3253.1 & 8009,9 & 63.54 & $36.5 \mathrm{~m}$ \\
\hline $10 / 1 / 2008$ & 2008.8 & TM & 5923.3 & 2986.6 & 9909.9 & 66.54 & $37.5 \mathrm{~N}$ \\
\hline $11 / 1 / 2006$ & 2008.4 & $\mathrm{TM}$ & 5963,4 & 2946,4 & moso.9. & 66.95 & $29.1 \%$ \\
\hline $9 / 2 / 2009$ & 2009.7 & $T M$ & 5835.7 & 3074,2 & 6909,9 & 65.55 & $34.5 \%$ \\
\hline $2 / 25 / 2010$ & 2010.2 & TM & 6165.9 & 2744.9 & apo9.9] & $09.2 \%$ & $30,8 \%$ \\
\hline
\end{tabular}

\begin{tabular}{|c|c|c|c|c|}
\hline \multicolumn{5}{|c|}{ Net Land Change by Time Pesled } \\
\hline Type & Interval & $\begin{array}{l}\text { Change } \\
\text { (acres) }\end{array}$ & $\begin{array}{l}\text { Period } \\
\text { (years) }\end{array}$ & 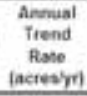 \\
\hline Aerial-atia: & 1595-395a & $-1363+1$ & 230 & -593 \\
\hline Aerial-Azerial & $11958-1055$ & 34.6 & 7.1 & 48.5 \\
\hline Lenal-Hab: & $1965-1973$ & 5239 & 19.7 & -39.0 \\
\hline \multicolumn{5}{|c|}{ Dates unodin Barras end others (2009) end Bamm $(2009)$} \\
\hline Hab-TM & 1978-2970 & 1699 & 12.0 & 14,1 \\
\hline$T M A-T M$ & $1990-2001$ & 285.3 & 11.0 & $-24,1$ \\
\hline TME.TM & $2001 \cdot 2004$ & 39 & 3.0 & 10.9 \\
\hline TMA-TME & $2004-2005$ & .386 .0 & 2.0 & -105.7 \\
\hline TM-TM & $2005-2008$ & 133.6 & 1.9 & 59.3 \\
\hline Aerial-TM & $1925-2010$ & -2.213 .4 & 75.2 & -30.0 \\
\hline \multicolumn{5}{|c|}{ munertute 2005 raniricmes } \\
\hline Dis & $2004-2005$ & -176.9 & 0.96 & $5 \quad-103.4$ \\
\hline
\end{tabular}

Data references:

Barras, 1. A, Eemier, IC, and Morton, R, A, 2008, Land area chunge in coustal Louisiand - A mulidecadal perspectine (from 1556 to 2006)i US. Gedicgical Sumvey scientific investigation

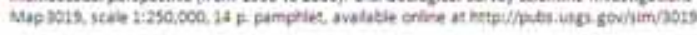

Barras, i, A, 2009, Land areacturge and sveniew of major humicare imsacts in coastal

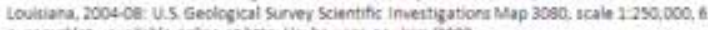

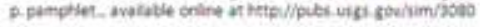

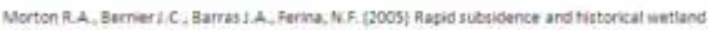
loss $n$ the south-central Massastipo deta plan; Liey cousen and Auture implications. U.S

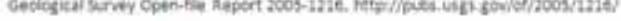

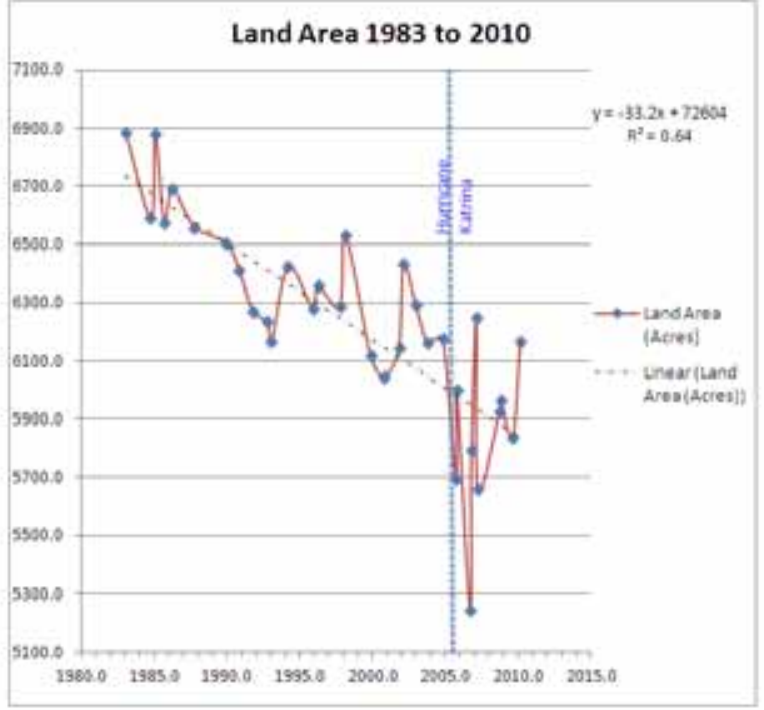

Slope or trend $=-33.2=4.5$ acres/yr from 1983 to 2010 e $95 \%$ confidence interval. Smple linear regression calculated using Prism statistics software.

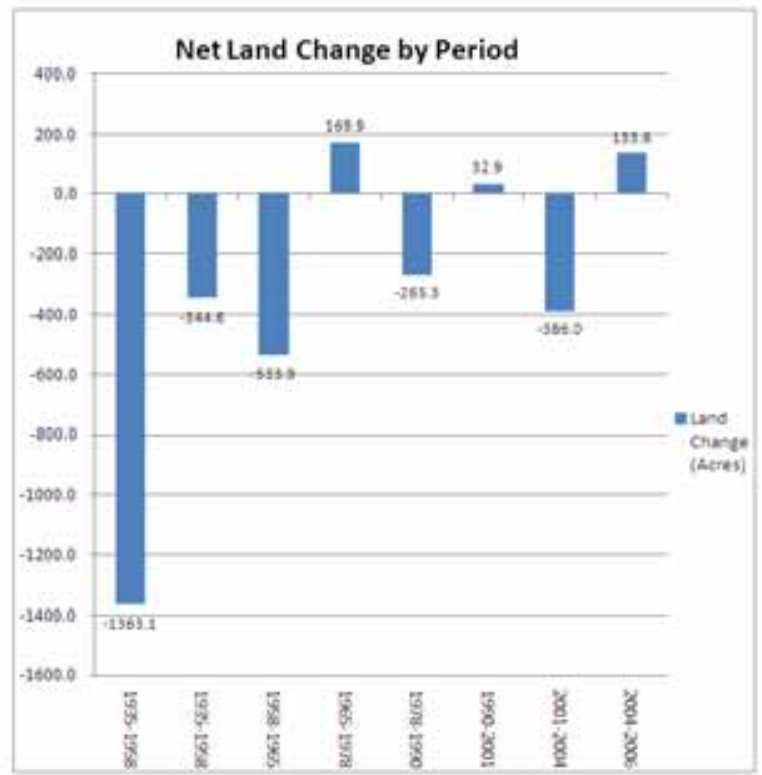


Table A5. Central Wetlands Unit - Impoundment Assessment Unit Area and Change Trends.

\begin{tabular}{|c|c|c|c|c|c|c|c|}
\hline & & & & & & & \\
\hline Date & Jution & Data & $\begin{array}{l}\text { Land } \\
\text { Area } \\
\text { (acres) }\end{array}$ & $\begin{array}{c}\text { Water } \\
\text { (acres) }\end{array}$ & $\begin{array}{c}\text { Total } \\
\text { (acres) }\end{array}$ & $\begin{array}{c}\% \\
\text { Land }\end{array}$ & water \\
\hline 1935 & 1935,0 & 0006 & 2420.6 & 125.1 & 3549,7 & $96.6 \mathrm{~N}$ & 2.46 \\
\hline 1958 & 2958.0 & Tobin pan & 3373.8 & 175.9 & 3548.7 & $75.0 \%$ & 5.05 \\
\hline $1 / 31 / 1965$ & 1955.1 & Tobin Pan & 2737.2 & 812.5 & 3549.7 & 77.14 & $22.9 \%$ \\
\hline $9 / 25 / 1974$ & 2997.6 & $C D R$ & 2497.8 & 205:-9 & 3849.7 & 43.24 & 57.06 \\
\hline $1 / 6 / 1903$ & 1983.0 & $T M$ & 1670.1 & 1079.6 & 3549.7 & $47.0 \mathrm{~N}$ & 53.05 \\
\hline $9 / 29 / 1964$ & 1984.7 & $\mathrm{TM}$ & 1532.5 & 2017.2 & 3549.7 & 43.24 & $56.8 \%$ \\
\hline 1/19/19A5 & 1985.1 & $T M$ & .0 & 1877.7 & 3549.7 & 47.14 & $52.94 \mathrm{~s}$ \\
\hline eys/19as & 3985.7 & $\mathrm{TM}$ & .7 & 2217.0 & 3549.7 & 37.54 & $62.5 \mathrm{~N}$ \\
\hline $3 / 27 / 1936$ & 1986.2 & $T M$ & 4 & 2 & 3549.7 & 43.34 & $56.7 \mathrm{~W}$ \\
\hline $50 / 8 / 19 \pi 7$ & เ987. & $T M$ & .1 & 2 & 3549.7 & 43.25 & 56.86 \\
\hline $1 / 17 / 1999$ & 1969.0 & Habitat & .5 & 1 & 3549.7 & $51.1 \%$ & 48.95 \\
\hline $12 / 15 / 1089$ & 1900.0 & $\mathrm{TM}$ & .4 & 2060.2 & 3549.7 & 42.05 & $58.04 \mathrm{~h}$ \\
\hline $12 / 1 / 1990$ & 1990.8 & $T M$ & is & 2179.2 & 3549.7 & 33.64 & 61.46 \\
\hline $50 / 31 / 1991$ & $1991 . a$ & $\mathrm{TM}$ & 2167.1 & 2302.6 & 3549,7 & 32.94 & 67.16 \\
\hline $10 / 5 / 1992$ & 1992.8 & $T M$ & 1226.9 & 2322.8 & 3549.7 & $34,6 \%$ & 65.476 \\
\hline $1 / 25 / 1993$ & 1993,1 & $\mathrm{TM}$ & 4 & 2400.3 & 3548.7 & $32+46$ & $67.6 \%$ \\
\hline $3 / 17 / 1994$ & 1904.2 & $\mathrm{TM}$ & 1365.6 & 2184.1 & 3548.7 & 38.54 & 61.54 \\
\hline $12 / 2 W / 1995$ & 1995.9 & $\mathrm{TM}$ & 2277.7 & 2272.0 & 3549.7 & 36.04 & 64.05 \\
\hline $4 / 7 / 1996$ & 2996.3 & $\operatorname{Tat}$ & 2249.0 & 2300.7 & 3549.7 & 35.24 & 64.86 \\
\hline to/3/1997 & 1997.8 & $T M$ & 1252,1 & 2297.6 & 3549.7 & $35.3 \%$ & $64.7 \%$ \\
\hline $2 / 24 / 1998$ & 1998.2 & $T M$ & 2344.4 & 2205.3 & 3549.7 & $37.9 \%$ & $62.1 \%$ \\
\hline $11 / 15 / 1999$ & 1999,9 & $T M$ & 1170.2 & 2271.4 & 2349.7 & $22.2 \mathrm{~N}$ & 66.65 \\
\hline $10 / 11 / 2000$ & 2000.9 & $T M$ & 1167,4 & 2303.3 & 3549.7 & $32.9 \%$ & 69.15 \\
\hline $10 / 30 / 200 !$ & 2001.0 & $\mathrm{TM}$ & 1224]$. & 2325.4 & 3549,7 & 34.54 & 65.56 \\
\hline $2 / 27 / 2002$ & 2002.2 & $T M$ & 1361.7 & 2188.0 & 3540.7 & $38.4 \%$ & 61.65 \\
\hline $12 / 28 / 2002$ & 2003,0 & $T M$ & 1258.4 & 22913 & 3549.7 & $35.5=\mathrm{k}$ & $64.5 \%$ \\
\hline $10 / 20 / 2003$ & 2003.9 & $\mathrm{TM}$ & 1178.5 & 2374.1 & 3549.7 & 33.24 & 66.05 \\
\hline $12 / 7 / 2004$ & 2004.9 & $\mathrm{TM}$ & 1170.4 & 237.3 & 3549,7 & 33.24 & 66.55 \\
\hline $10 / 9 / 2005$ & 2005,8 & $T M$ & 910.1 & 2639.6 & 3549,7 & $25.6 \%$ & $74,4 \%$ \\
\hline $10 / 25 / 2005$ & 2005.8 & $\mathrm{TM}$ & 1017.3 & 25324 & 3549.7 & $28.7 \%$ & $\pi 1.34$ \\
\hline $9 / 26 / 2006$ & 2006.7 & $\mathrm{TM}$ & 860.5 & 2689.1 & 3549.7 & 24.246 & 75,656 \\
\hline $10 / 20 / 3006$ & 2006.4 & $T M$ & 972.7 & 2577.0 & 3549,7 & $27,4 \%$ & $72.6 \mathrm{~s}$ \\
\hline $2 / 7 / 2007$ & 2007.2 & $\mathrm{TM}$ & 1124,5 & 2425.2 & 3549.7 & 34.76 & 60.36 \\
\hline $4 / 6 / 2007$ & 2007,3 & $T M$ & 926.6 & 2625.0 & 3549.7 & $26.0 \%$ & $74.05 \%$ \\
\hline $10 / 1 / 2000$ & 2008.8 & $T M$ & 1027.0 & 2522.6 & 3549.7 & $28.9 \%$ & $71.1 \%$ \\
\hline $11 / 1 / 2000$ & 2006.8 & $T M$ & 1051.3 & 2490.4 & 3548.7 & $29.0 \%$ & $70.4 \mathrm{~s}$ \\
\hline $9 / 2 / 2009$ & 2009.7 & $\mathrm{TM}$ & 2019.6 & 2530.1 & 3549,7 & $2 a .75$ & 71.26 \\
\hline $2 / 25 / 2010$ & 2010.2 & $\mathrm{TM}$ & 1055.3 & 2494.4 & 3549.7 & 29.74 & 30.34 \\
\hline
\end{tabular}

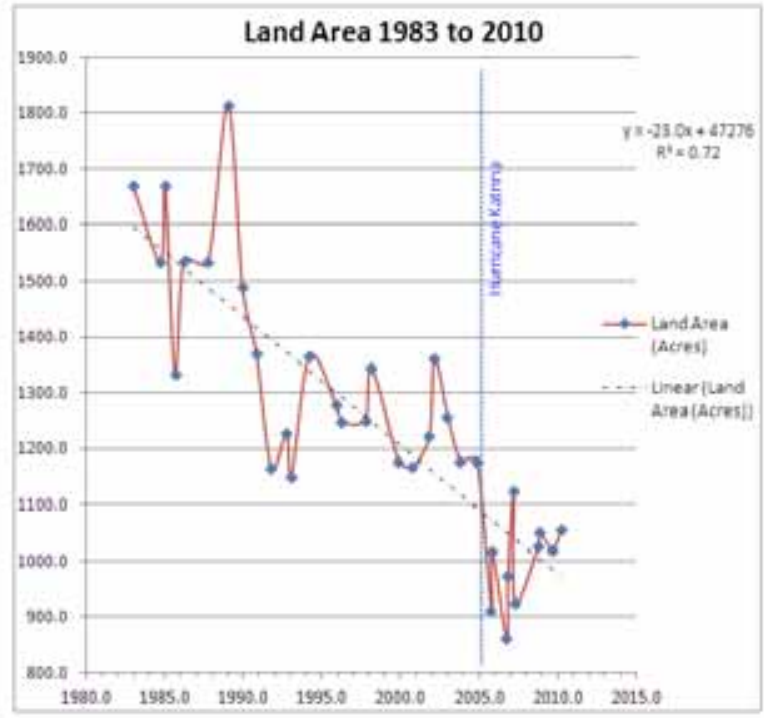

Slope or trend $=-23.0 \pm 2.6$ actes/yr from 1983 to 2010 e $95 \%$ confidence interval. Simple inear regression calculated using Prism statistes soitware.

\begin{tabular}{|c|c|c|c|c|}
\hline \multicolumn{5}{|c|}{ Met Land Changen by Time Prrisd } \\
\hline Tyese & nterval & $\begin{array}{l}\text { Change } \\
\text { (acrest }\end{array}$ & $\begin{array}{l}\text { Denod } \\
\text { Gearsi }\end{array}$ & $\begin{array}{l}\text { Aonvial } \\
\text { Trend } \\
\text { Rate } \\
\text { incinsm }\end{array}$ \\
\hline Aeriat-Aeria & $1935-1958$ & SA & $2 n 0$ & 24 \\
\hline Aerial-Aeria & $1954-1965$ & 5964 & 71 & क⿻ \\
\hline Aerial-Hab & $1965-1970$ & .9920 & 137 & 725 \\
\hline \multicolumn{5}{|c|}{ 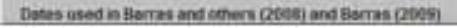 } \\
\hline Hab-TM & $1978-1990$ & 3747 & 120 & अ1 \\
\hline TME-TM & $1990 \cdot 2001$ & .452 & 110 & .133 \\
\hline$T M-T M$ & $2001-2004$ & 45.9 & 30 & .152 \\
\hline TME-TM & $2004-2006$ & 2005.7 & 2.0 & -1043 \\
\hline TM: TME & $2000=2000$ & 543 & 1.9 & 20.2 \\
\hline Aerial-TM & $1935-2010$ & 2373.3 & 75.2 & 31.6 \\
\hline \multicolumn{5}{|c|}{ Inmender 2005 Hericanes. } \\
\hline DTM & $2004-2005$ & .161 .1 & 096 & .1670 \\
\hline
\end{tabular}

Datareferences:

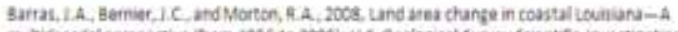

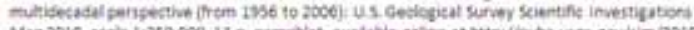

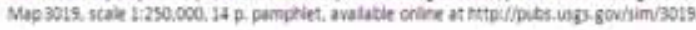

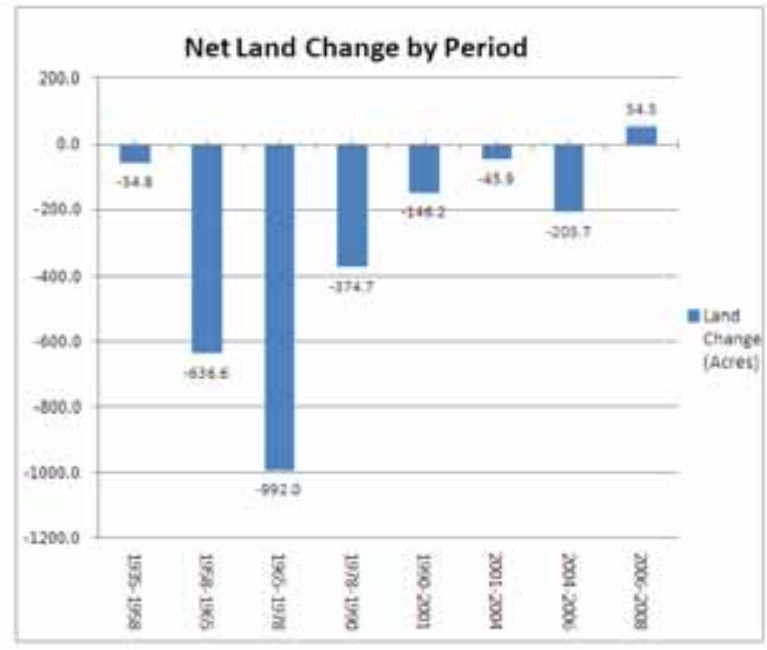

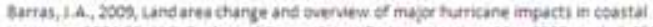

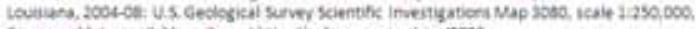

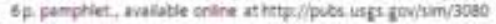

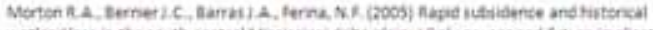


Table A6. Central Wetlands Unit - MRGO Dredged Material Placement Assessment Unit Area and Change Trends.

\begin{tabular}{|c|c|c|c|c|c|c|c|}
\hline Date & Ulian & Data & $\begin{array}{l}\text { Land } \\
\text { Area } \\
\text { (acres) }\end{array}$ & $\begin{array}{c}\text { water } \\
\text { (acres) }\end{array}$ & $\begin{array}{c}\text { Total } \\
\text { (acres) }\end{array}$ & $\begin{array}{c}\% \\
\text { Land }\end{array}$ & $\begin{array}{c}\text { कb } \\
\text { Water }\end{array}$ \\
\hline 1935 & 19350 & DAG & 8168.0 & 380.5 & 6568.5 & $94.25 \mathrm{~s}$ & 5.89 \\
\hline 1958 & 1958.0 & Tobin Dan & 155.8 & 1412.7 & 6568.9 & $78,5 \%$ & 2139 \\
\hline $1 / 31 / 1965$ & 1955.t & Tobin Dan & 3609.5 & $\cos .0$ & A5sa.s & \$9. 816 & 10.24 \\
\hline $9 / 15 / 1974$ & 1974.6 & $C I R$ & 52712 & 1297.3 & 6558.9 & $80.2 \%$ & $19.8 \%$ \\
\hline 1/6/293 & 1983.0 & $\mathrm{n}$ & 36. & $931 . ?$ & 6560.5 & $15.0 \mathrm{~s}$ & 34.25 \\
\hline $4 / 0 / 1904$ & t98a.3 & $\pi$ & 22.5 & 945.0 & 65814.5 & as.os & 14.45 \\
\hline $9 / 29 / 1964$ & 19647 & $\mathrm{n}$ & 5580.5 & 968.0 & 6556.9 & $85.09 \%$ & $1509=$ \\
\hline $1 / 29 /$ tgas & t9es.t. & $\mathrm{n}$ & 55530 & tors.s & 6560.5 & $0.9 \mathrm{~N}$ & 15.9 \\
\hline $8 / 31 / 1965$ & 1985) & u & 8.9 & 9126 & As5a.s & as.15 & 139 \\
\hline $2 / 27 / 19 e 6$ & 1986.2 & M & 1.4 & 5037.8 & 45se.s & 14.26 & 15.84 \\
\hline $10 / 8 / 1987$ & 1987.8 & $\mathrm{~m}$ & 48.3 & 1020.2 & 6558.5 & $84.5 \%$ & is 39 \\
\hline 1/2a/19a8 & 1968.1 1 & $\pi$ & क1.7 & 1000.8 & 4568.9. & 54.75 & 183. \\
\hline $1 / 17 / 1909$ & 1989.9 & Hacien & 2 & 929.3 & 45sa.5 & 14.94\% & 15.10 \\
\hline $11 / 1 / 1990$ & 1990.8 & $\mathrm{nu}$ & 73.0 & 993.3 & 6558.9 & 84.896 & 15.20 \\
\hline to/ $12 / 399 \mathrm{~s}$ & 1991.8 & $\pi$ & 80 & 1040.9 & 656a.9. & E.95 & $15.9 \mathrm{~N}$ \\
\hline $10 / 5 / 1992$ & 1992.8 & $\pi$ & 00.7 & 1058.8 & 6568.5 & $\$ 3.996$ & 16.150 \\
\hline $1 / 25 / 1993$ & t99: & no & 2.4 & 1096.: & 635a.9. & 63) & 1678 \\
\hline $3 / 17 / 1994$ & 1994 & $u$ & 8.9 & 1012.6 & 6560.3 & $84.6 \%$ & $5,4=$ \\
\hline $11 / 15 / 1995$ & 1995.9 & & 7.3 & 10712 & 6568.9 & $\$ 3.75$ & 6.39 \\
\hline $4 / 7 / 1996$ & t990.3 & . & 12.7 & 3094.9 & 635a.9. & eas & 16.36 \\
\hline $10 / 3 / 1997$ & 1997.6 & $\mathrm{nt}$ & 52.1 & 1016.4 & 656a. S & 64.5\% & 5.99 \\
\hline $2 / 24 / 199$ & t & 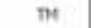 & . & 0.9 & 65se.s & $03.6 \%$ & 16.45 \\
\hline 999 & 19 & TM & Ls & 1036.9 & 6568.5 & $84.2 \%$ & 15.89 \\
\hline 000 & 2000.6 & M & 0 & 5044.5 & 656a.s & a4.1\% & 15.94 \\
\hline $10 / 30$ & 2001.6 & $M$ & 12 & 1047.3 & 6560,5 & $34: 15$ & 15.94 \\
\hline 1002 & 2002.2 & m. & 8 & 999.7 & 6568.9 & $84.85 \%$ & $15.2 \%$ \\
\hline $12 / 20 / 2002$ & 2003.0 & & 0 & to71.5 & 656e.s. & as $7 \%$ & 16.3 \\
\hline $10 / 20 / 2003$ & 2003.6 & $\pi$ & 50 & 1023.5 & 655a, 5 & 174.45 & 15.6 \\
\hline $12 / 7 / 2004$ & 200 & $\mathrm{~m}$ & 2.6 & $159 a .9$ & 6560.5 & at. 76 & $\tan x$ \\
\hline $10 / 9 / 2005$ & 2005 & $\mathrm{TM}$ & 43.3 & 1225.2 & 655e.s & 61. $3 \%$ & 16.79 \\
\hline $50 / 25 / 2005$ & 2005 & $\pi$ & 4as & 1120.0 & 6584.5 & 02.96 & 17,14 \\
\hline $9 / 26 / 2006$ & 2006.7 & wo & 108. & 1161.7 & 456a.5 & a2.36 & 17.76 \\
\hline $10 / 28 / 2006$ & 2000.6 & In & 5375.6 & 1192.9 & 6556.5 & $81.8 \%$ & $18.2 \%$ \\
\hline $3 / 7 / 2007$ & 2007.2 & $\pi$ & 5292.1 & 1176.4 & S56ulas & a2.15 & 17.56 \\
\hline $4 / 6 / 2007$ & 2007.3 & $\mathrm{n}$ & 5396.6 & 1169.9 & 6568.9 & 82.25 & 17.958 \\
\hline $10 / 2 / 2000$ & 2000.8 & $\mathrm{~m}$ & 39876 & 1200.9 & 656e.5 & at. $2 \mathrm{w}$ & $10.3 \mathrm{~s}$ \\
\hline $11 / 1 / 2006$ & 2006.6 & $\mathrm{TM}$ & 10.3 & 1178.2 & A556.9 & \$2.15 & 17.590 \\
\hline 2000 & 2009,7 & $\mathrm{~m}$ & & 1152.6 & \$5sa.s & 02.94 & $17.9 \mathrm{~s}$ \\
\hline $2 / 25 / 2010$ & 2010.2 & $\mathrm{n}$ & 32000 & t1es.s & 656e.5) & $12.0 \mathrm{~s}$ & 10.9 \\
\hline
\end{tabular}

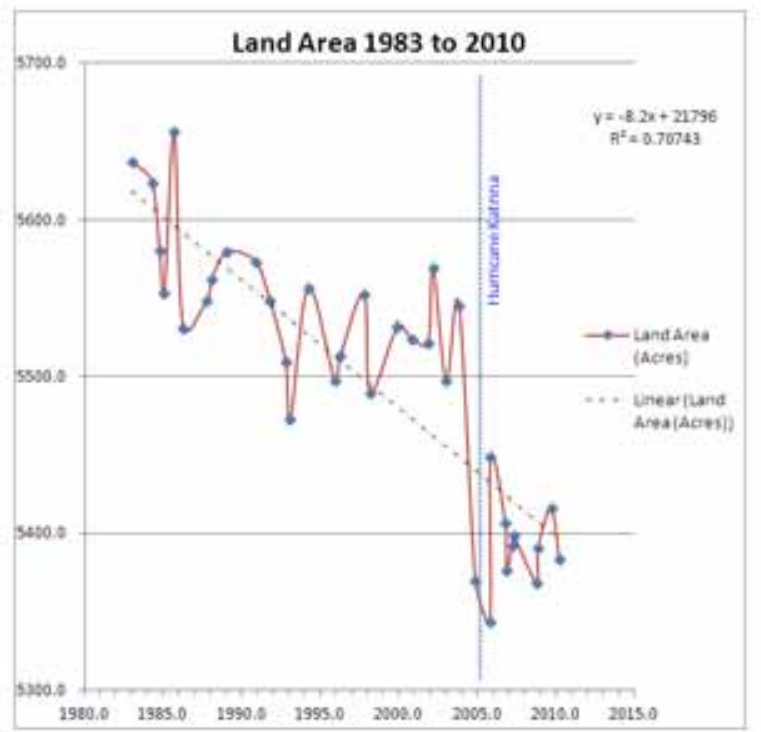

Slope or trend $=-8.2=0.9$ scres/yr from 1983 to 2010 o $95 \%$ confidence interval. Simple linesr regression calculated using Prism statistics software.

\begin{tabular}{|c|c|c|c|c|}
\hline \multicolumn{5}{|c|}{ Neat Lass Change by Time Period } \\
\hline Tnpe & interval & $\begin{array}{l}\text { Orespe } \\
\text { (ecress) }\end{array}$ & $\begin{array}{l}\text { Dentios } \\
\text { cears) }\end{array}$ & 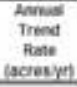 \\
\hline Aeria-Aerval & $1935-1958$ & 10321 & 230 & 44 \\
\hline Aeriat-Aeruat & 195a-1965 & $70 \%$ & 71 & toet \\
\hline Aeriak kab & $1965-1978$ & 3511 & 13.7 & -26.4 \\
\hline \multicolumn{5}{|c|}{ 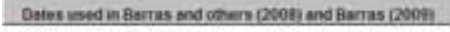 } \\
\hline $\mathrm{Hab}-\mathrm{TM}$ & $1978-1960$ & 346 & 12.0 & 2.9 \\
\hline TM:TM & $1990-2001$ & -51.8 & 11.0 & .4 .7 \\
\hline TM:TM & $2001-2004$ & 4516 & 3.0 & -50.2 \\
\hline TME:TM & $2004-2000$ & 60 & 200 & 2.8 \\
\hline$T M-T M$ & $2006: 2009$ & -4.0 & 1.8. & -4.2 \\
\hline Lenal $T M$ & $1925-2010$ & $=004.9$ & 75.2 & -10.7 \\
\hline \multicolumn{5}{|c|}{ Uirmedate 2005 iterncanes } \\
\hline-1 & 4-2005 & $\pi 9$ & 9.95 & 81.8 \\
\hline
\end{tabular}

Docaraferences:

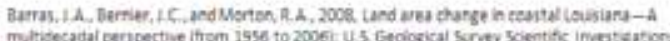

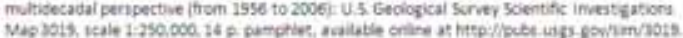

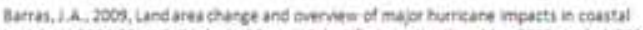

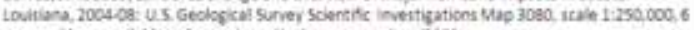

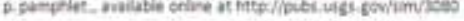

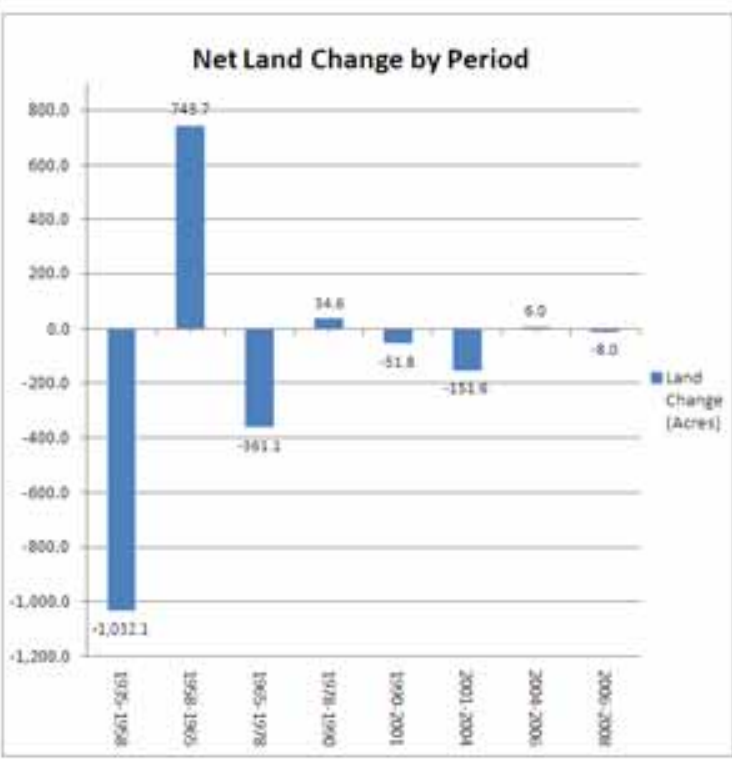

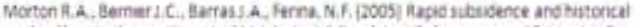

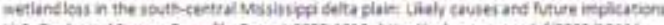

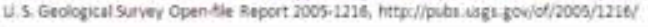


Table A7. Central Wetlands Unit - Assessment Units Forested Area Trends.

\section{Central Wetlands - Assessment Units}

1935

MRGO Dredged Material Placement Hurricane Impacts and Marsh Bayou Bienvenue North

Forested Wetlands

Impoundment Area

Total (Acres)

\section{6}

MRGO Dredged Material Placement Hurricane Impacts and Marsh

Bayou Bienvenue North

Forested Wetlands

Impoundment Area

Total (Acres)

1965

MRGO Dredged Material Placement Hurricane Impacts and Marsh

Bayou Bienvenue North

Forested Wetlands

Impoundment Area

Total (Acres)

1974

MRGO Dredged Material Placement Hurricane Impacts and Marsh

Bayou Bienvenue North

Forested Wetlands

Impoundment Area

Total (Acres)

\begin{tabular}{rrrrr}
\hline $\begin{array}{r}\text { Land Area } \\
\text { (acres) }\end{array}$ & $\begin{array}{r}\text { Forested } \\
\text { Wetlands } \\
\text { (Acres) }\end{array}$ & $\begin{array}{r}\text { Dredged } \\
\text { Material } \\
\text { (Acres) }\end{array}$ & $\begin{array}{r}\text { Water } \\
\text { (acres) }\end{array}$ & $\begin{array}{r}\text { Total } \\
\text { (acres) }\end{array}$ \\
\hline 5192.9 & 995.1 & 0.0 & 380.5 & 6568.5 \\
8338.4 & 141.3 & 0.0 & 430.1 & 8909.9 \\
2117.8 & 1373.0 & 0.0 & 102.9 & 3593.7 \\
36.9 & 9110.5 & 0.0 & 105.8 & 9253.2 \\
1124.0 & 2304.6 & 0.0 & 121.1 & 3549.7 \\
\hline \hline 16810.1 & 13924.4 & 0.0 & 1140.4 & 31874.9
\end{tabular}

\begin{tabular}{rrrrr}
\hline $\begin{array}{r}\text { Land Area } \\
\text { (acres) }\end{array}$ & $\begin{array}{r}\text { Forested } \\
\text { Wetlands } \\
\text { (Acres) }\end{array}$ & $\begin{array}{r}\text { Dredged } \\
\text { Material } \\
\text { (Acres) }\end{array}$ & $\begin{array}{l}\text { Water } \\
\text { (acres) }\end{array}$ & $\begin{array}{r}\text { Total } \\
\text { (acres) }\end{array}$ \\
\hline 4568.6 & 587.2 & 0.0 & 1412.7 & 6568.5 \\
6945.9 & 170.8 & 0.0 & 1793.2 & 8909.9 \\
2142.8 & 1140.3 & 0.0 & 310.6 & 3593.7 \\
2560.2 & 6556.8 & 0.0 & 136.2 & 9253.2 \\
1324.8 & 2049.0 & 0.0 & 175.9 & 3549.7 \\
\hline \hline 17542.3 & 10504.0 & 0.0 & 3828.6 & 31874.9
\end{tabular}

\begin{tabular}{rrrrr}
\hline $\begin{array}{r}\text { Land Area } \\
\text { (acres) }\end{array}$ & $\begin{array}{r}\text { Forested } \\
\text { Wetlands } \\
\text { (Acres) }\end{array}$ & $\begin{array}{r}\text { Dredged } \\
\text { Material } \\
\text { (Acres) }\end{array}$ & $\begin{array}{r}\text { Water } \\
\text { (acres) }\end{array}$ & $\begin{array}{r}\text { Total } \\
\text { (acres) }\end{array}$ \\
\hline 347.6 & 67.3 & 5484.6 & 669.0 & 6568.5 \\
6570.2 & 201.9 & 0.0 & 2137.8 & 8909.9 \\
2776.8 & 288.5 & 0.0 & 528.3 & 3593.7 \\
3448.6 & 5517.6 & 0.0 & 287.0 & 9253.2 \\
2120.9 & 616.3 & 0.0 & 812.5 & 3549.7 \\
\hline \hline 15264.1 & 6691.6 & 5484.6 & 4434.6 & 31874.9
\end{tabular}

* Due to the underestimation of water area in the 1956 NWI data, the 1958 water data was substituted in its place.

\begin{tabular}{rrrrr}
\hline $\begin{array}{r}\text { Land Area } \\
\text { (acres) }\end{array}$ & $\begin{array}{r}\text { Forested } \\
\text { Wetlands } \\
\text { (Acres) }\end{array}$ & $\begin{array}{r}\text { Dredged } \\
\text { Material } \\
\text { (Acres) }\end{array}$ & $\begin{array}{c}\text { Water } \\
\text { (acres) }\end{array}$ & $\begin{array}{r}\text { Total } \\
\text { (acres) }\end{array}$ \\
\hline 373.3 & 0.0 & 4897.9 & 1297.3 & 6568.5 \\
6125.1 & 0.0 & 0.0 & 2784.7 & 8909.9 \\
2951.5 & 0.0 & 0.2 & 642.0 & 3593.7 \\
8222.6 & 0.0 & 0.0 & 1030.6 & 9253.2 \\
1497.8 & 0.0 & 0.0 & 2051.9 & 3549.7 \\
\hline \hline 19170.3 & 0.0 & 4898.1 & 7806.5 & 31874.9
\end{tabular}




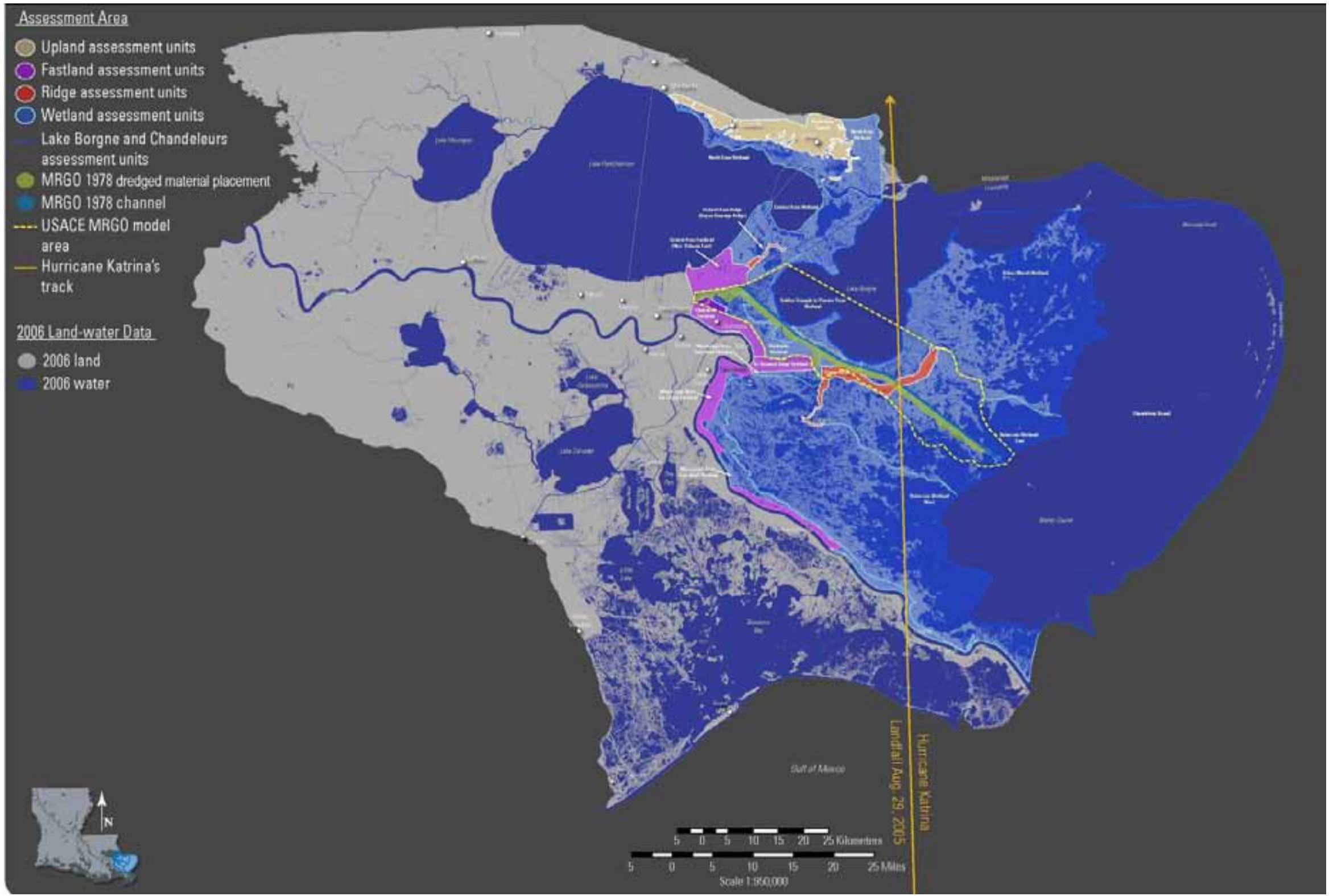




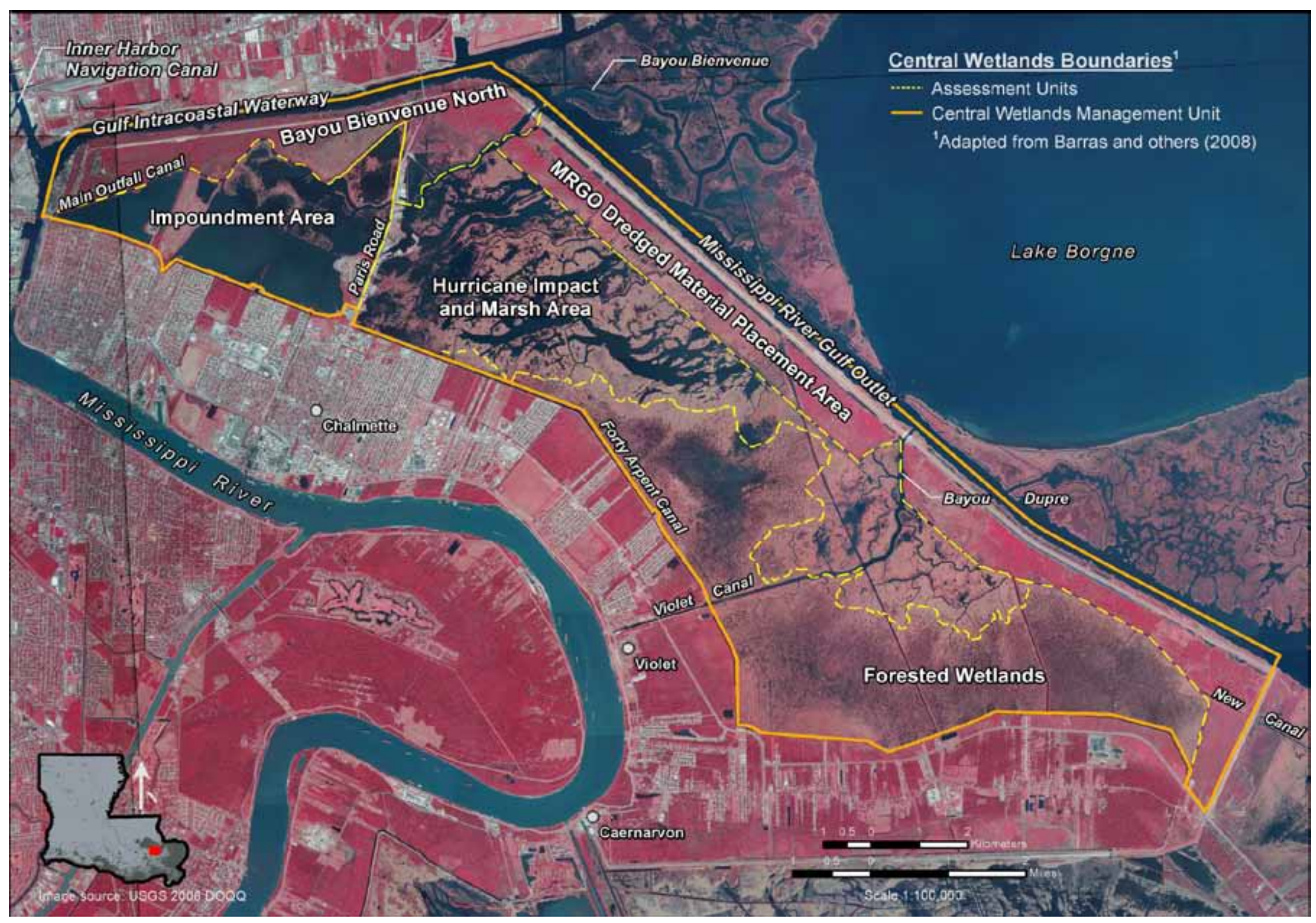

Figure A2. Mississippi River Gulf Outlet (MRGO) Central Wetlands Assessment Units. 


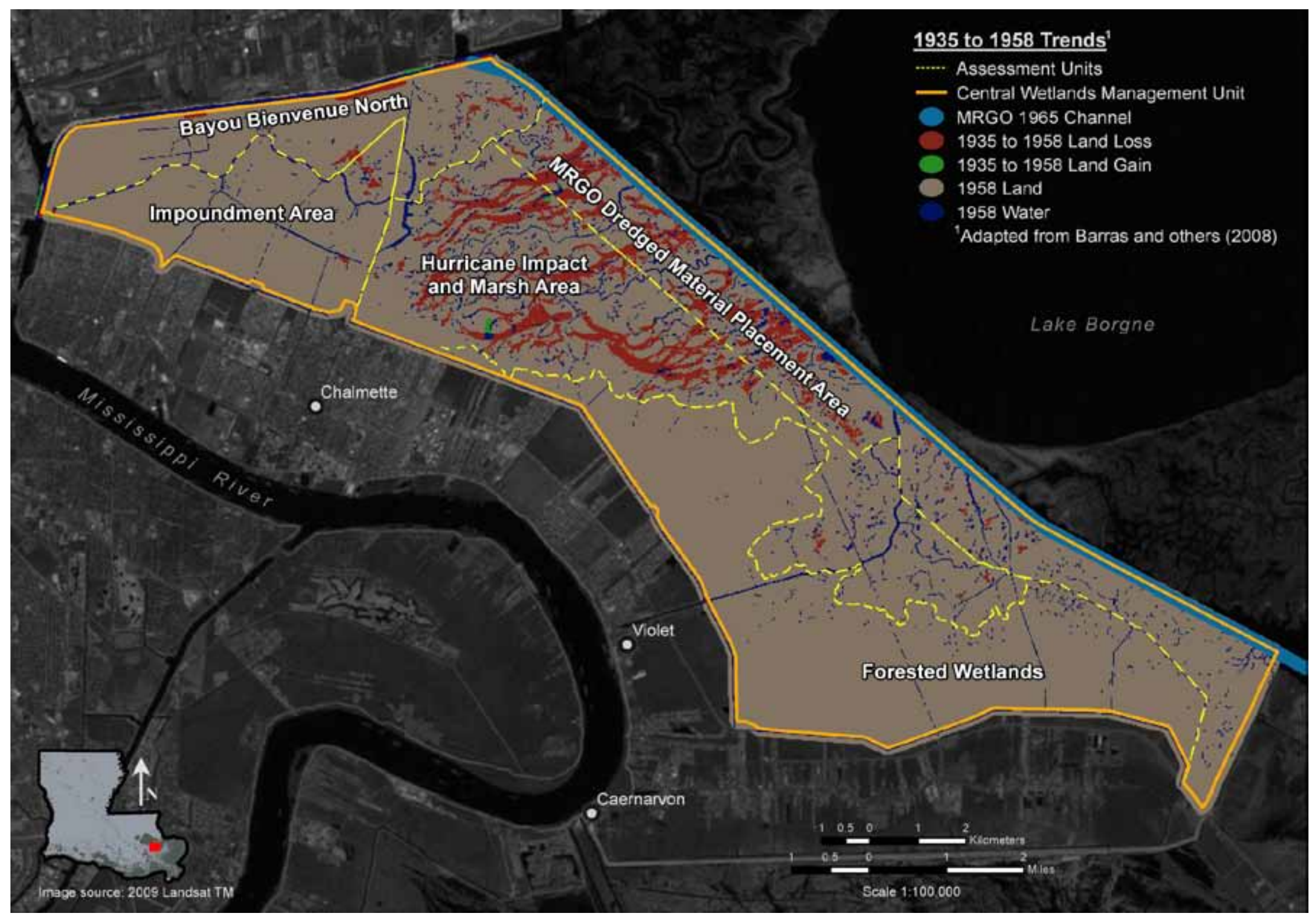

Figure A3. Mississippi River Gulf Outlet (MRGO) Central Wetlands Assessment Units, 1935 to 1958 Trends. 


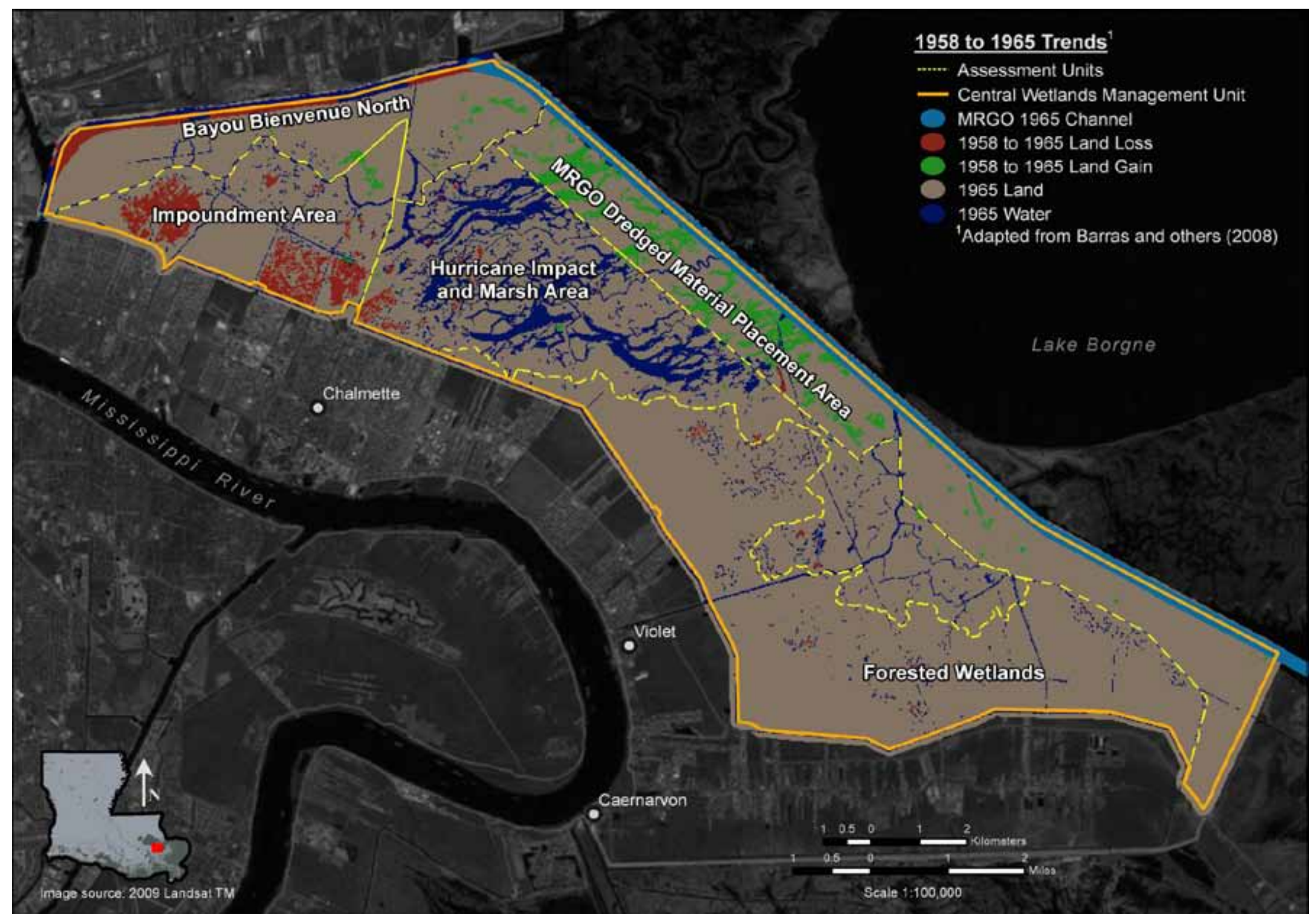

Figure A4. Mississippi River Gulf Outlet (MRGO) Central Wetlands Assessment Units, 1958 to 1965 Trends. 


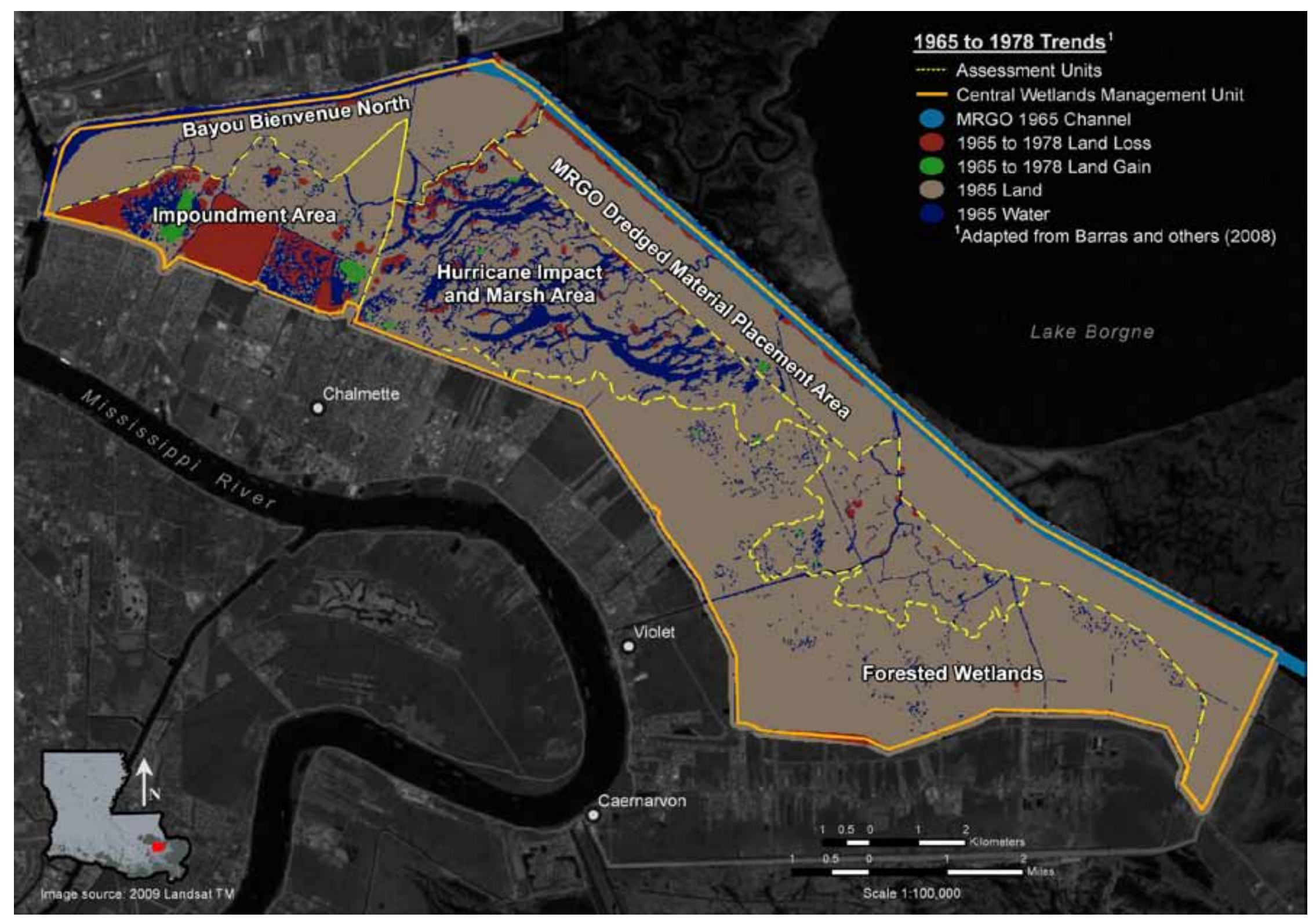

Figure A5. Mississippi River Gulf Outlet (MRGO) Central Wetlands Assessment Units, 1965 to 1978 Trends. 


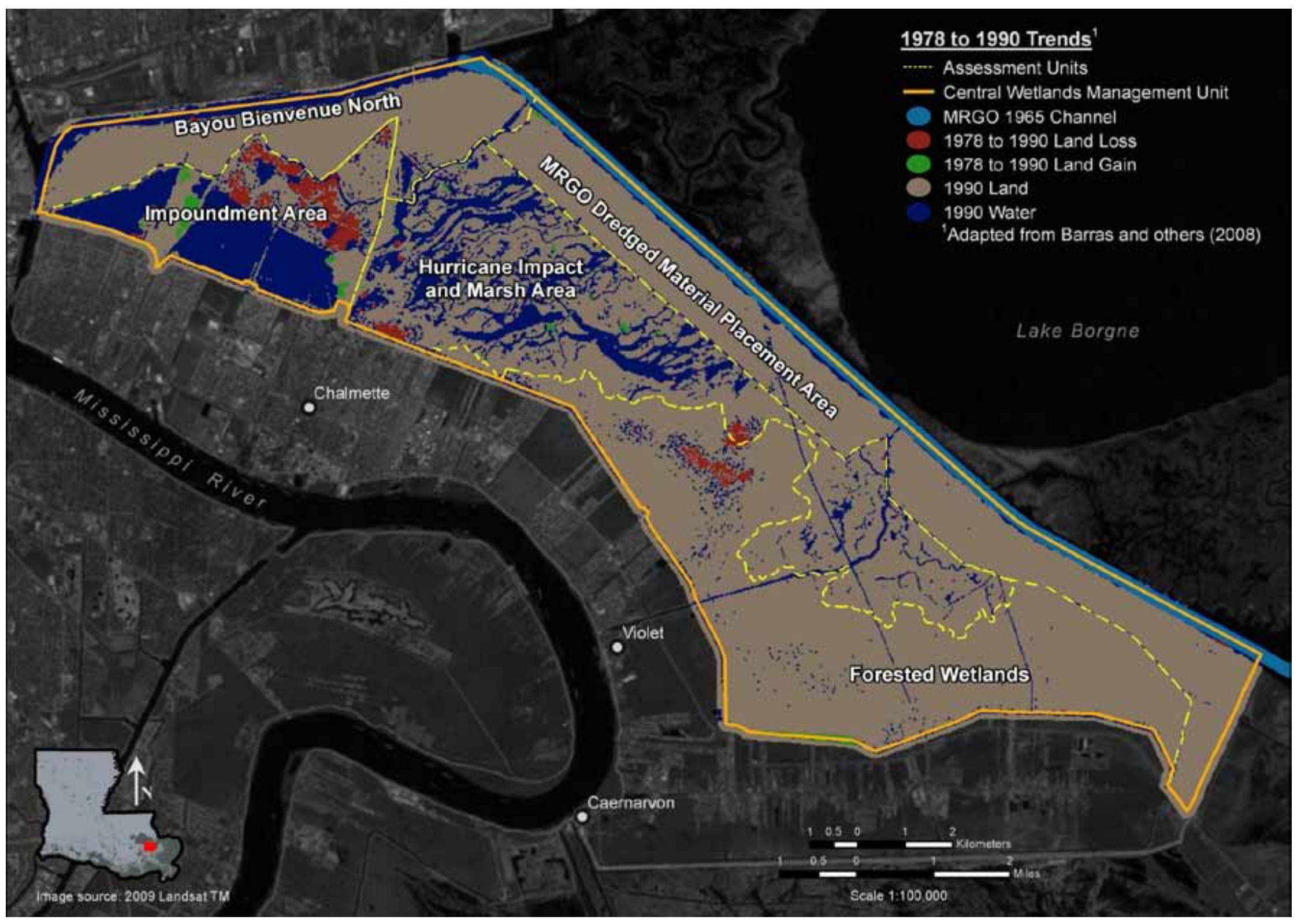

Figure A6. Mississippi River Outlet (MRGO) Central Wetlands Assessment Units, 1978 to 1990 Trends. 


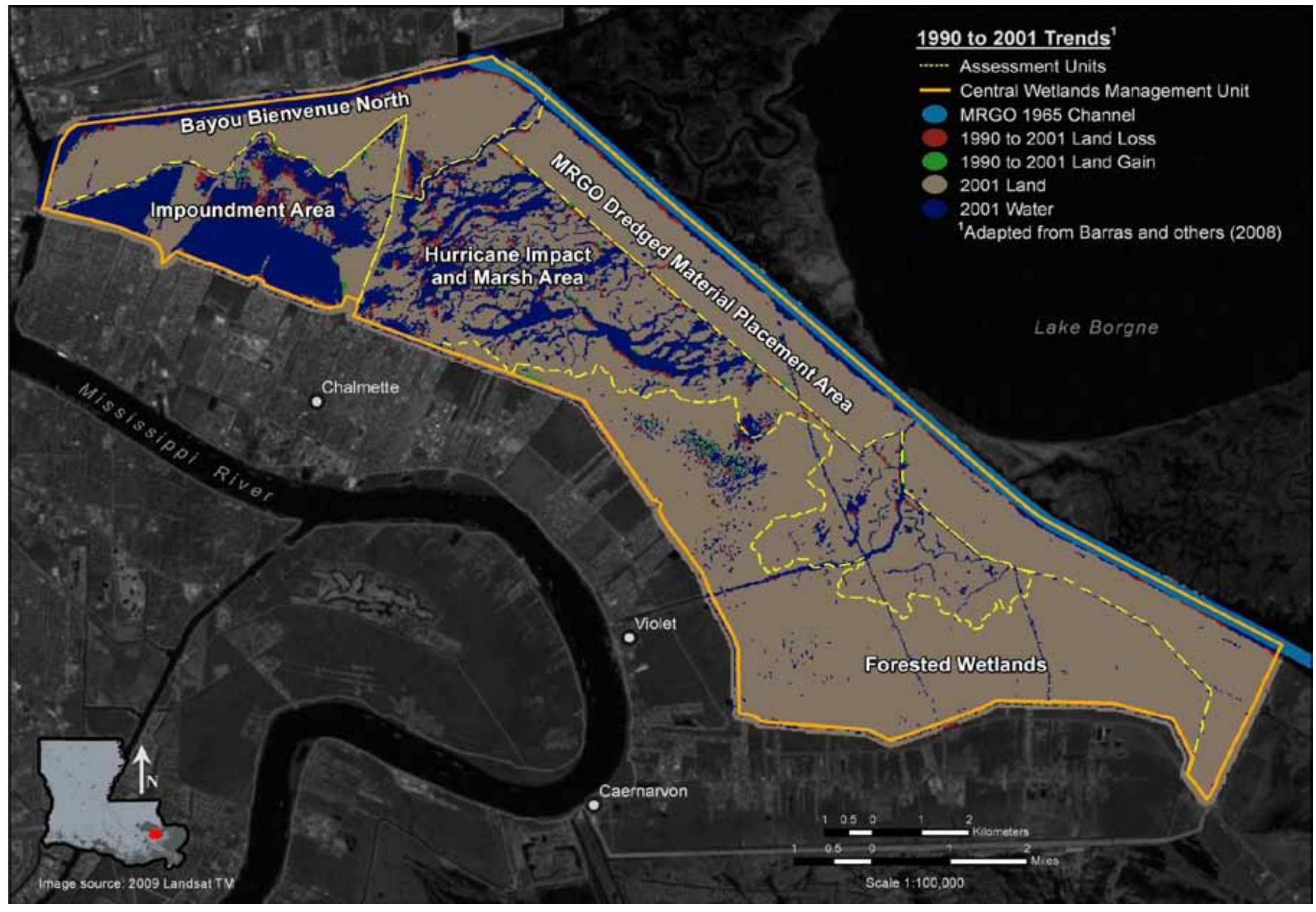

Figure A7. Mississippi River Gulf Outlet (MRGO) Central Wetlands Assessment Units, 1990 to 2001 Trends. 


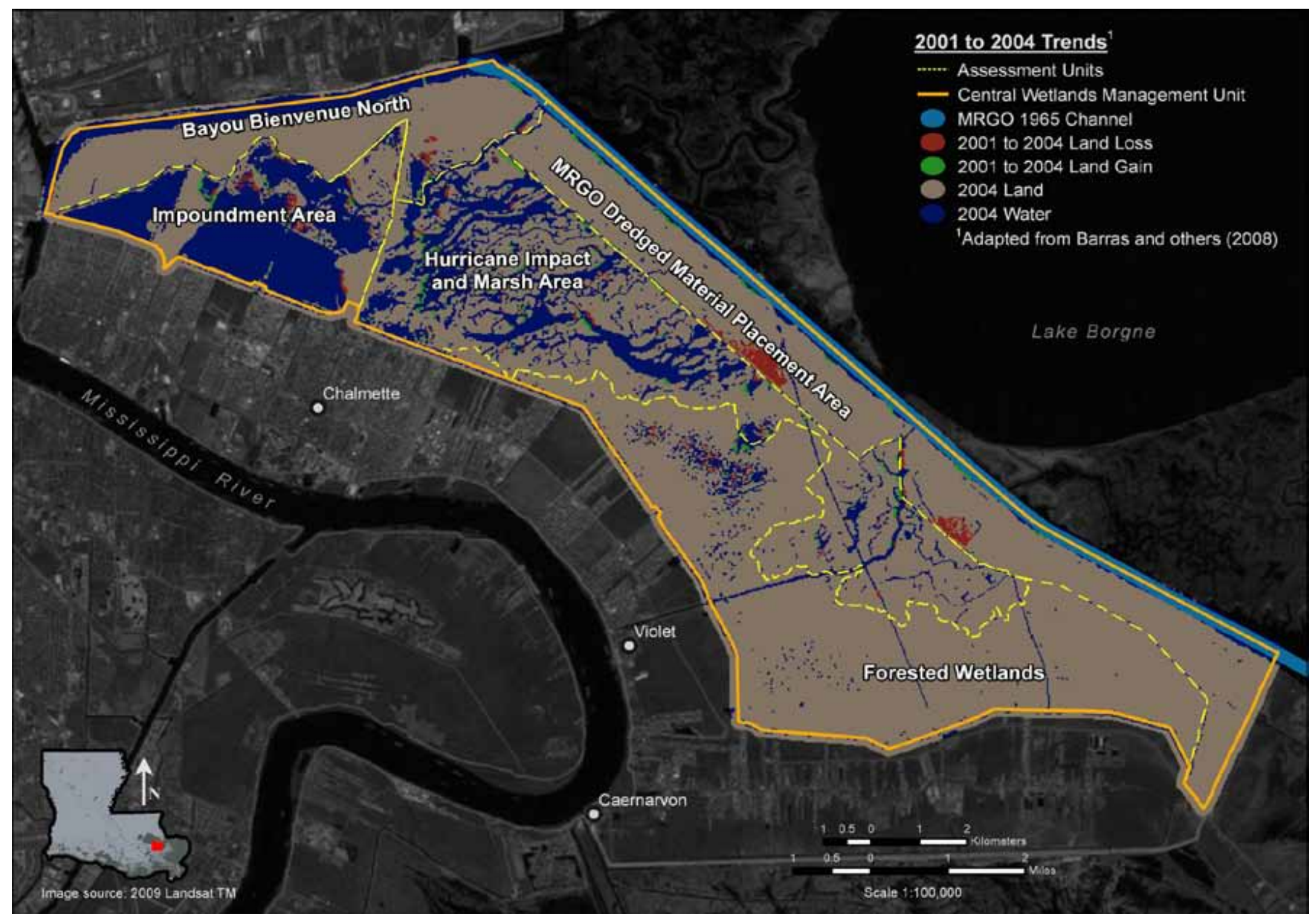

Figure A8. Mississippi River Gulf Outlet (MRGO) Central Wetlands Assessment Units, 2001 to 2004 Trends. 


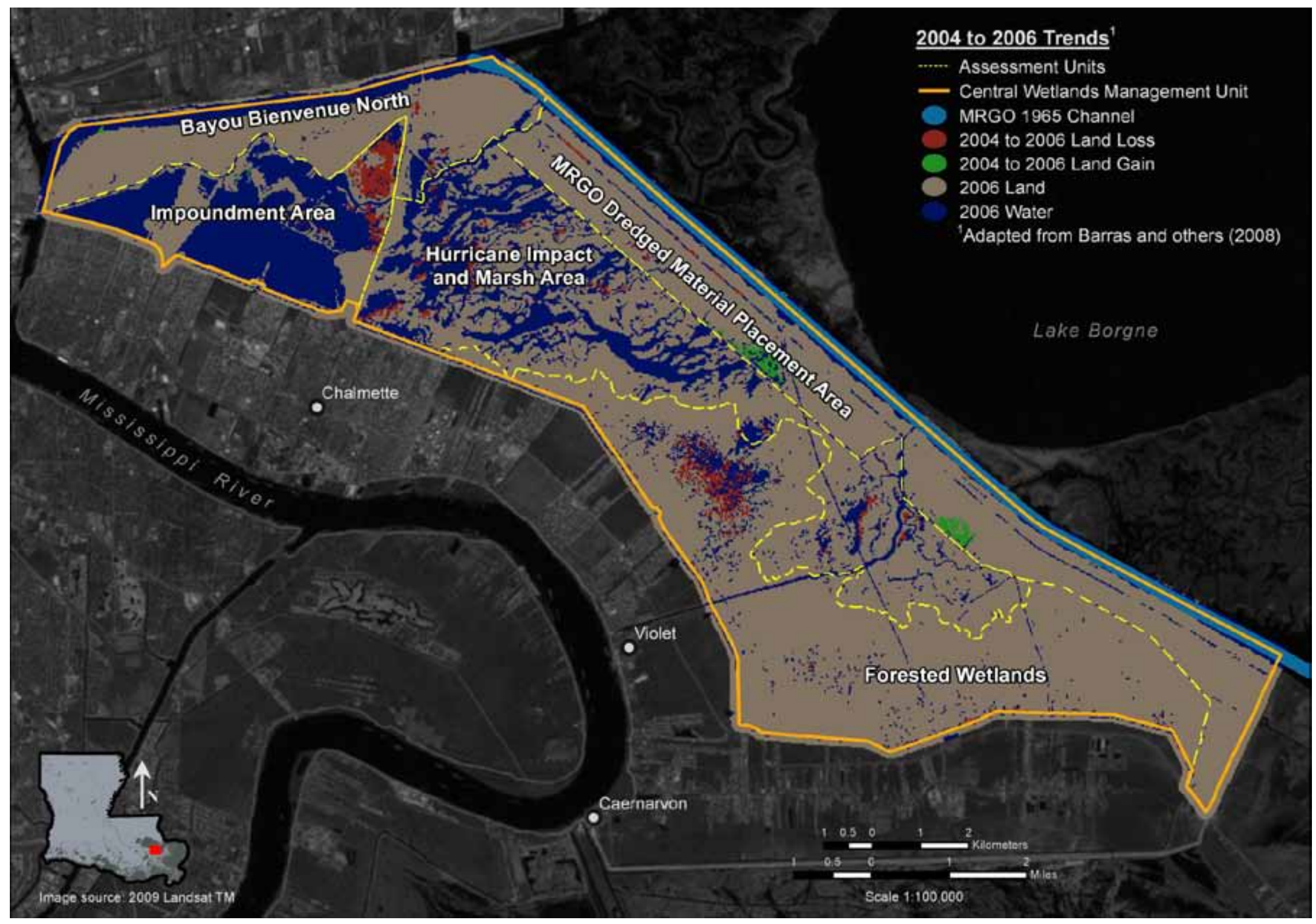

Figure A9. Mississippi River Gulf Outlet (MRGO) Central Wetlands Assessment Units, 2004 to 2006 Trends. 


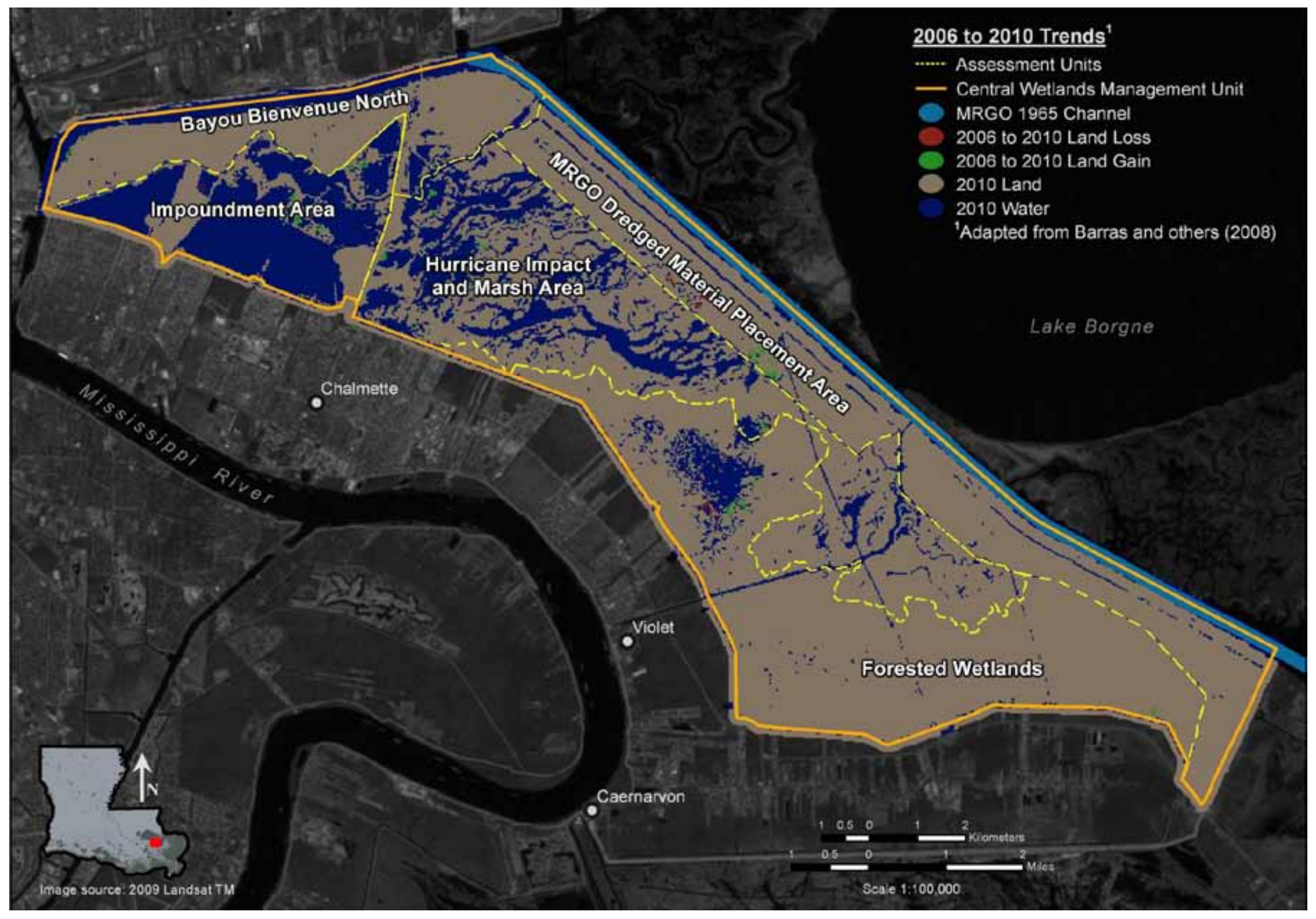

Figure A10. Mississippi River Gulf Outlet (MRGO) Central Wetlands Assessment Units, 2006 to 2010 Trends. 


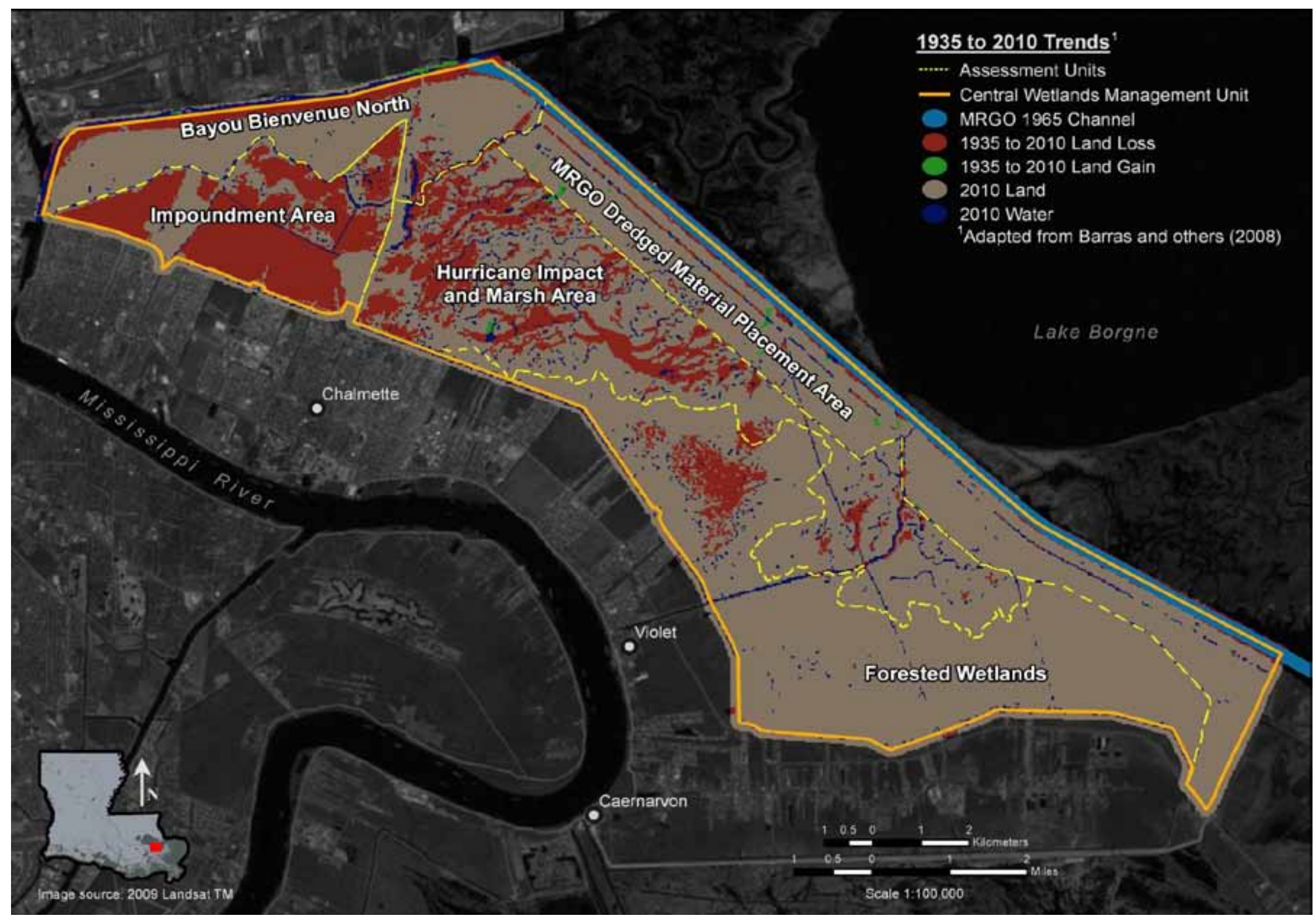

Figure A11. Mississippi River Gulf Outlet (MRGO) Central Wetlands Assessment Units, 1935 to 2010 Trends. 


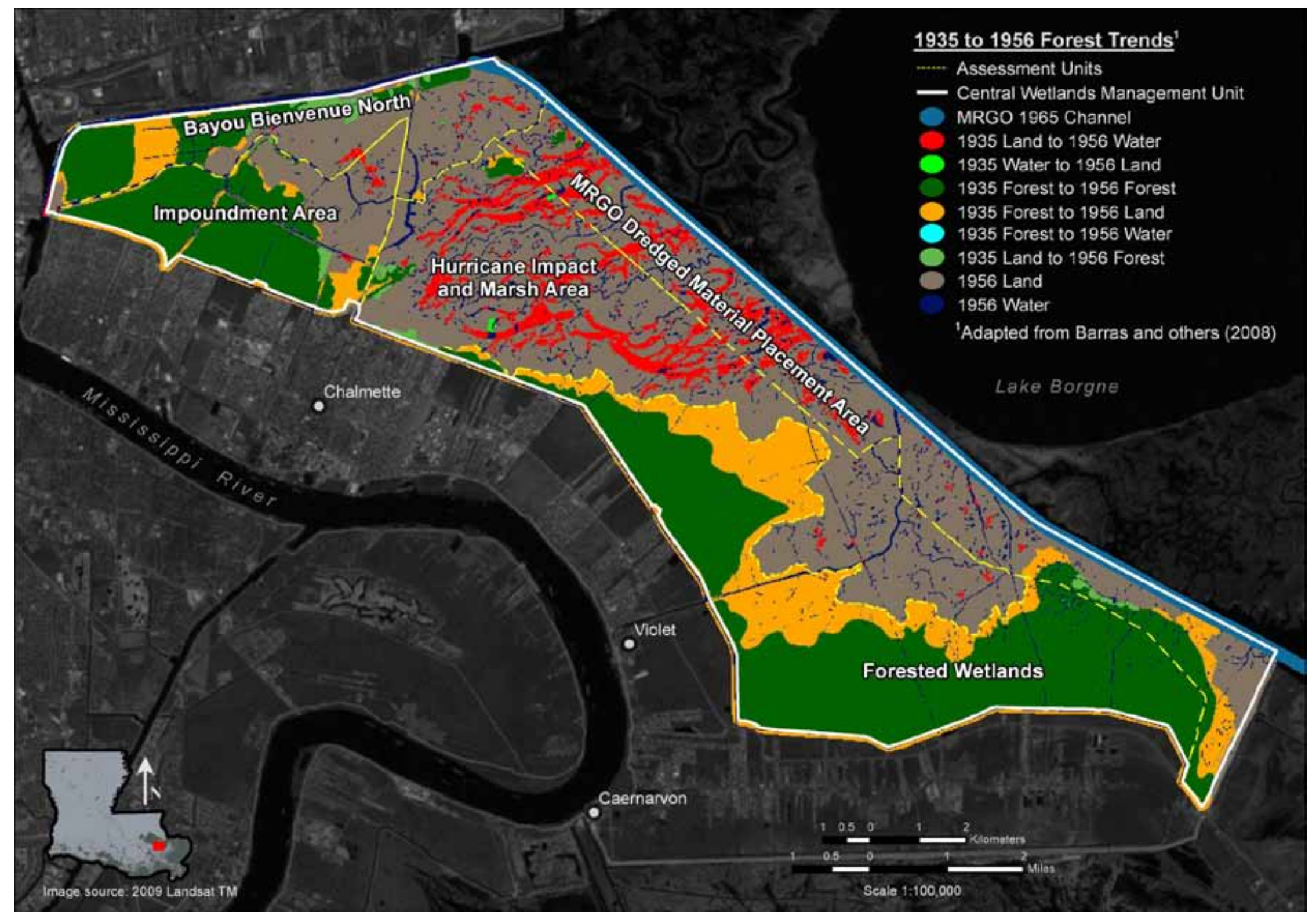

Figure A12. Mississippi River Gulf Outlet (MRGO) Central Wetlands Assessment Units, 1935 to 1956 Forest Area Trends. 


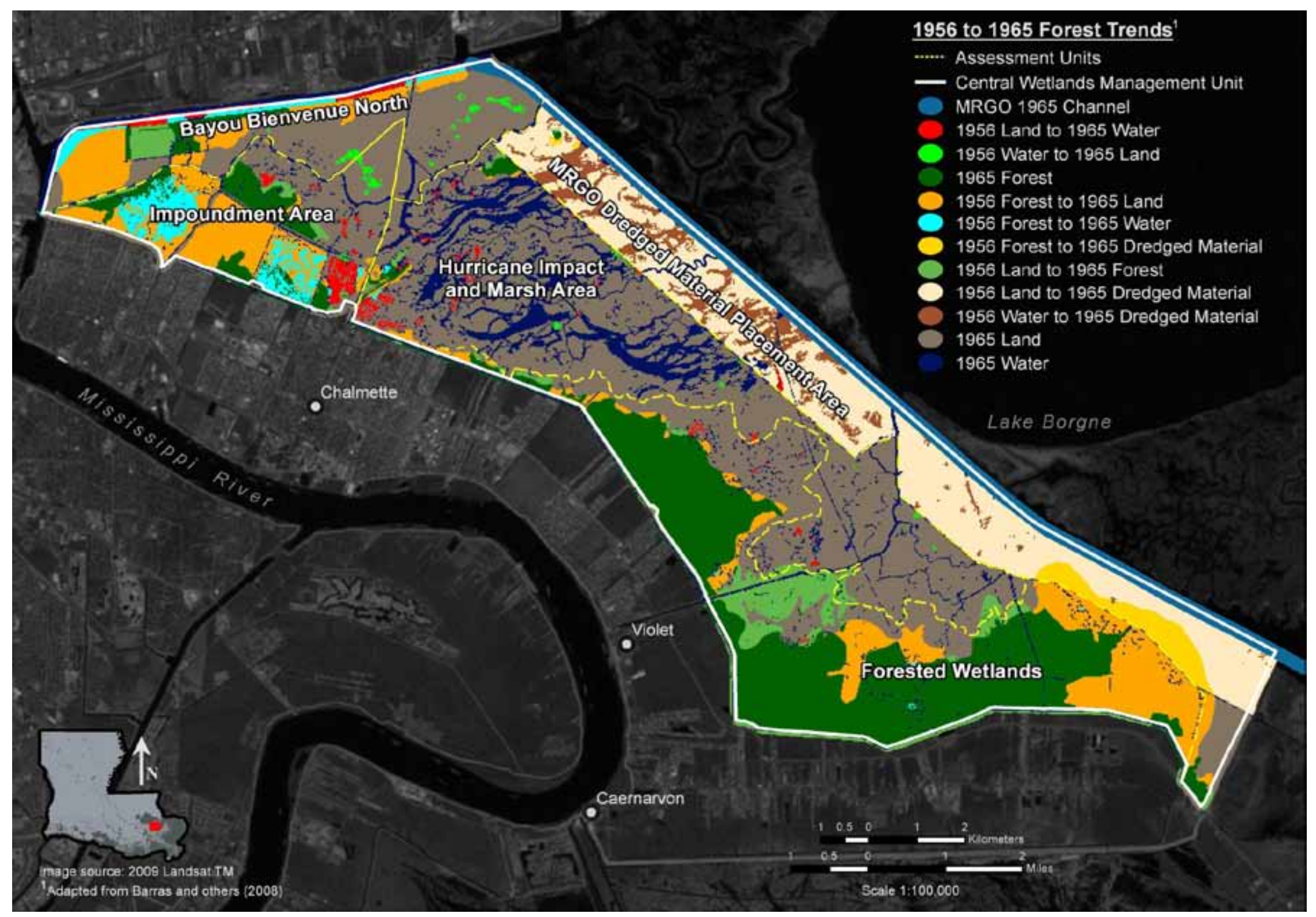

Figure A13. Mississippi River Gulf Outlet (MRGO) Central Wetlands Assessment Units, 1956 to 1965 Forest Area Trends. 


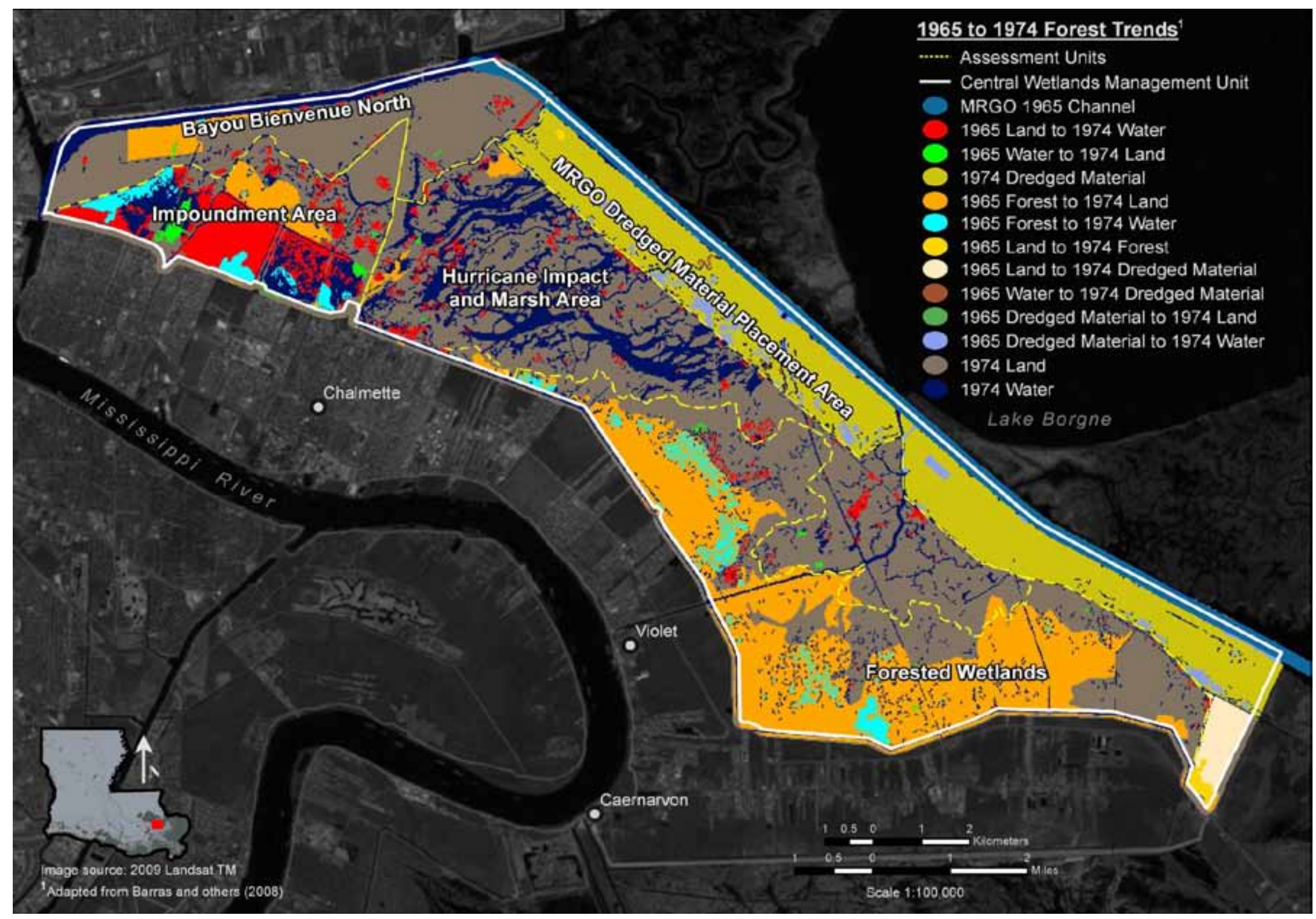

Figure A14. Mississippi River Gulf Outlet (MRGO) Central Wetlands Assessment Units, 1965 to 1974 Forest Area Trends. 


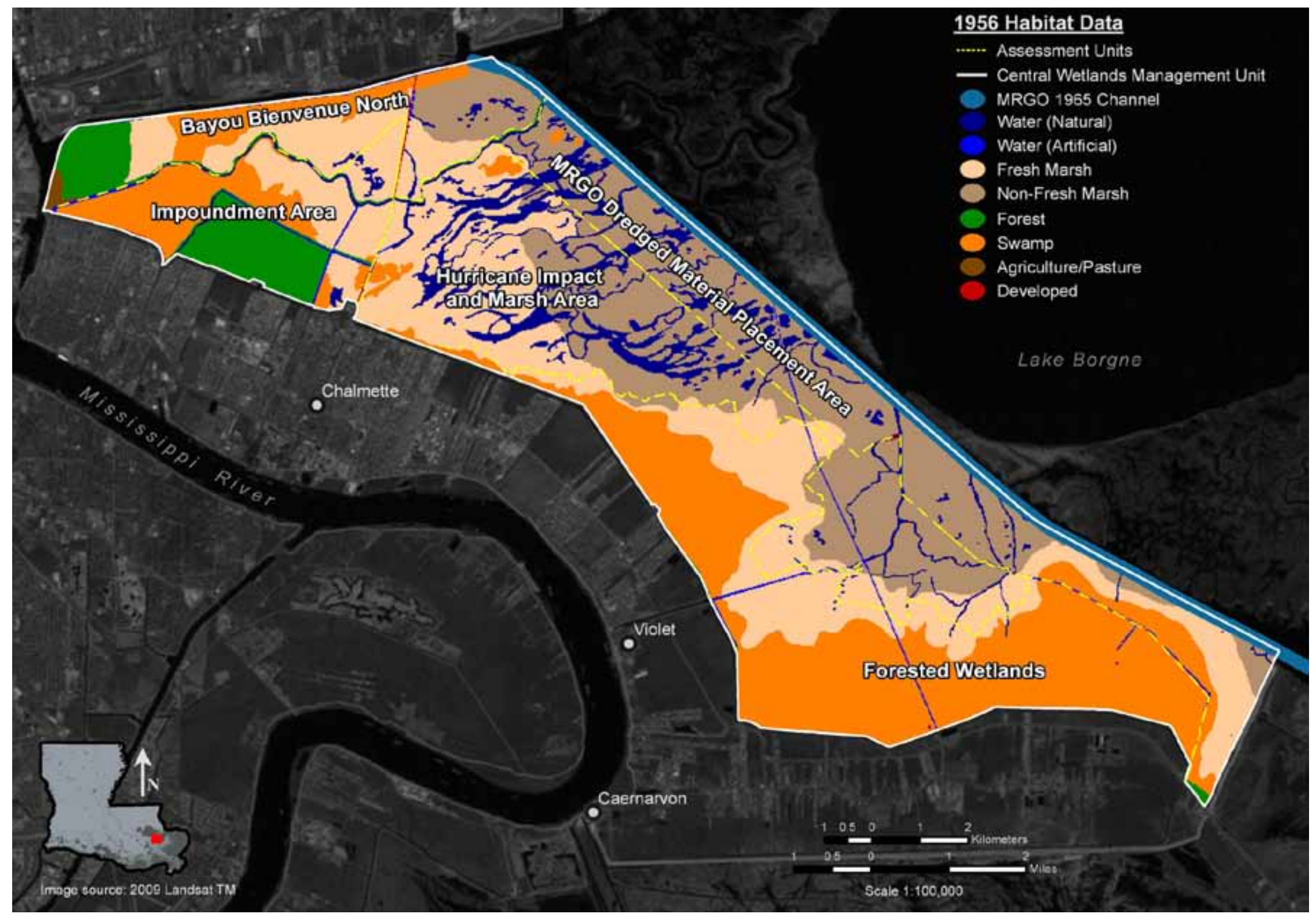

Figure A15. Mississippi River Gulf Outlet (MRGO) Central Wetlands Assessment Units, 1956 Habitats. 


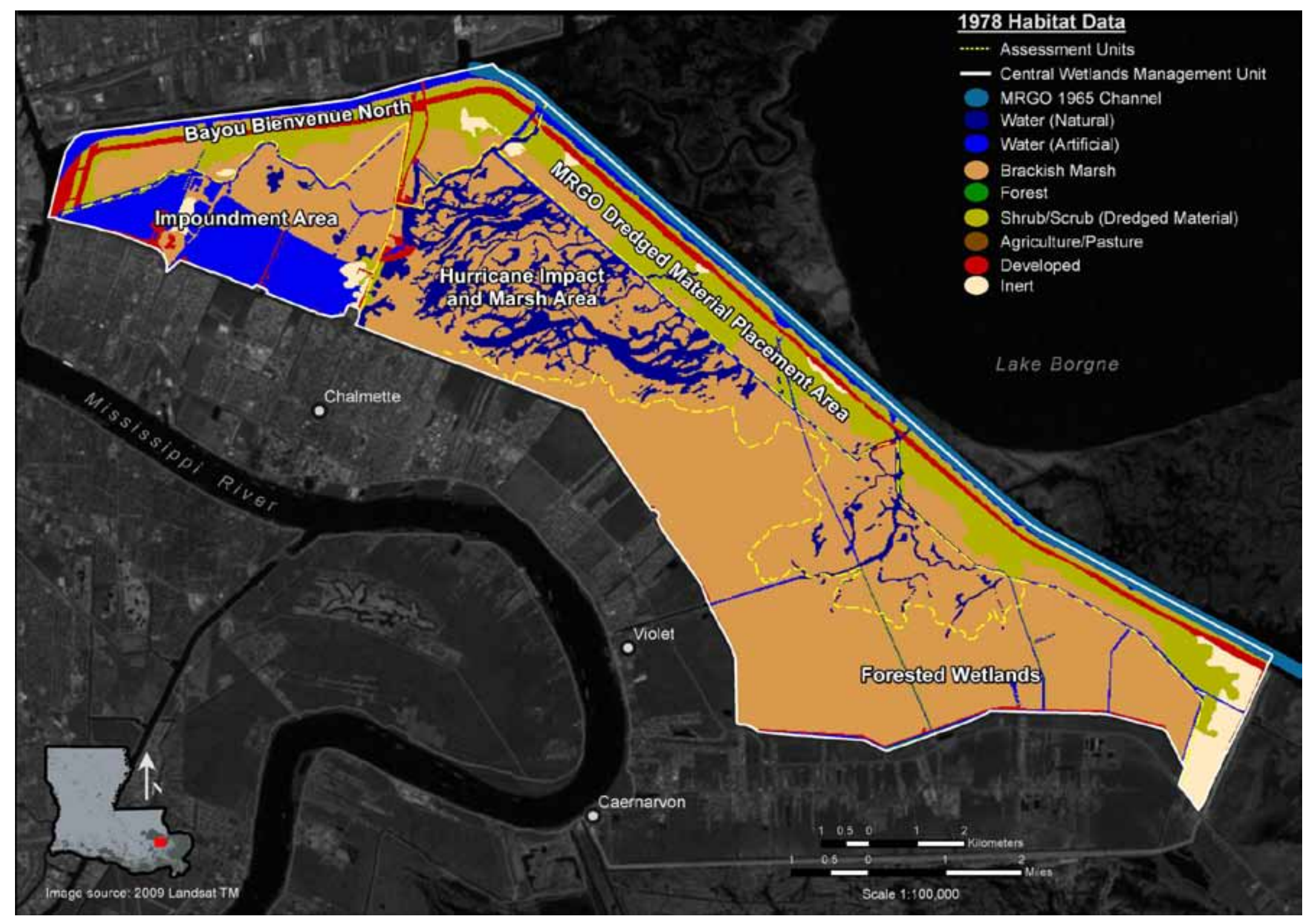

Figure A16. Mississippi River Gulf Outlet (MRGO) Central Wetlands Assessment Units, 1978 Habitats. 


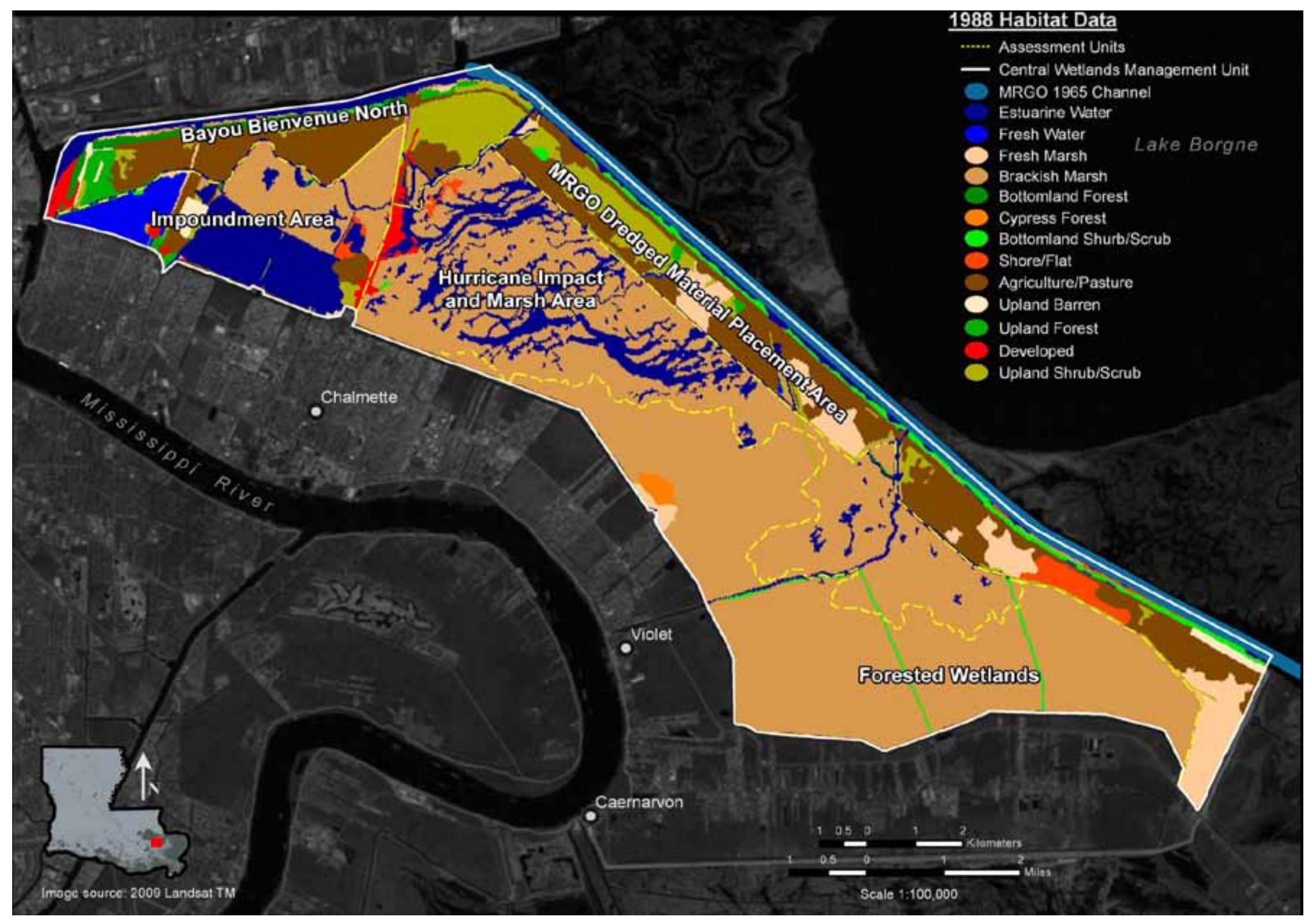

Figure A17. Mississippi River Gulf Outlet (MRGO) Central Wetlands Assessment Units, 1988 Habitats. 


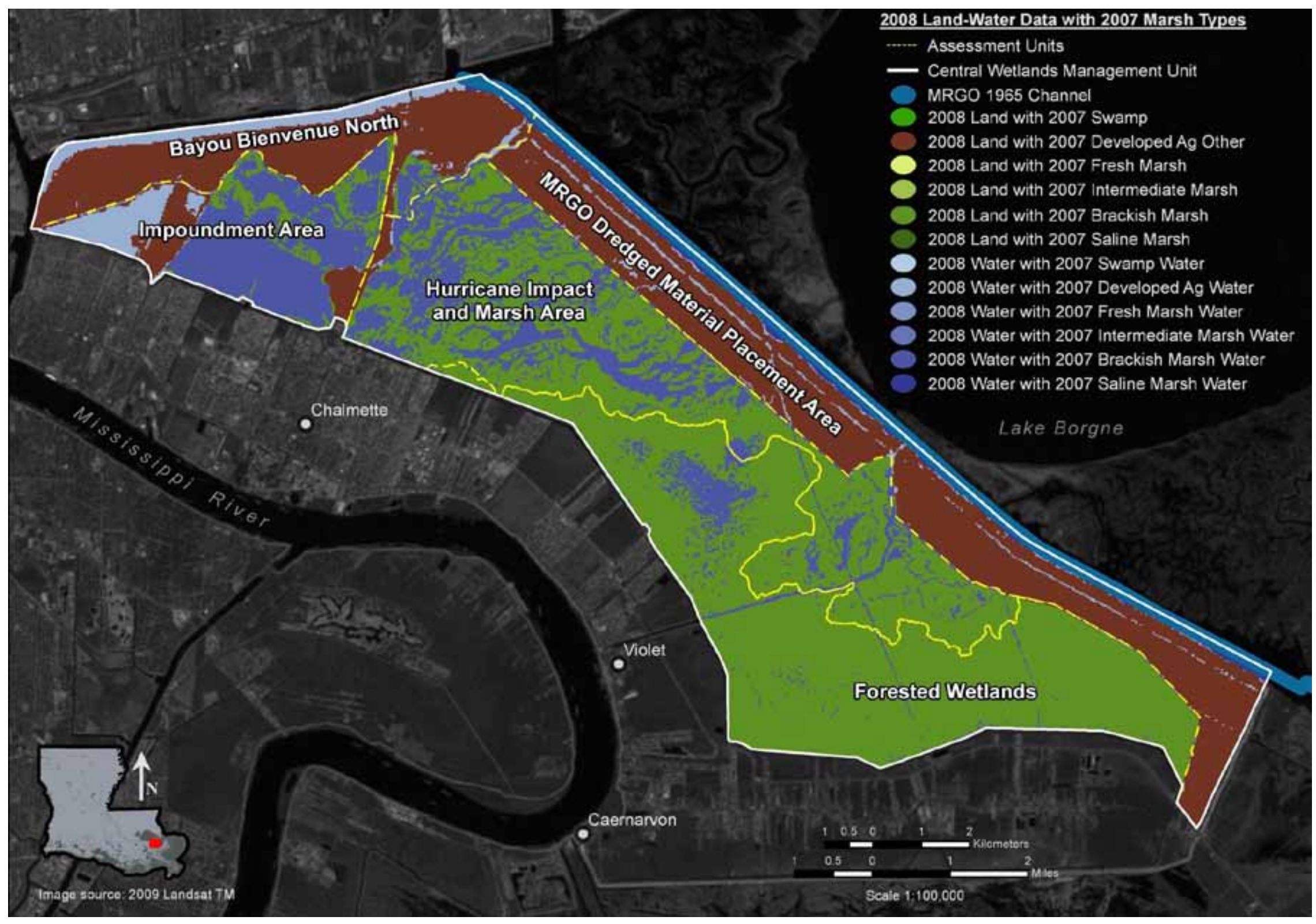

Figure A18. Mississippi River Gulf Outlet (MRGO) Central Wetlands Assessment Units, 2008 Land-Water Data with 2007 Marsh Types. 


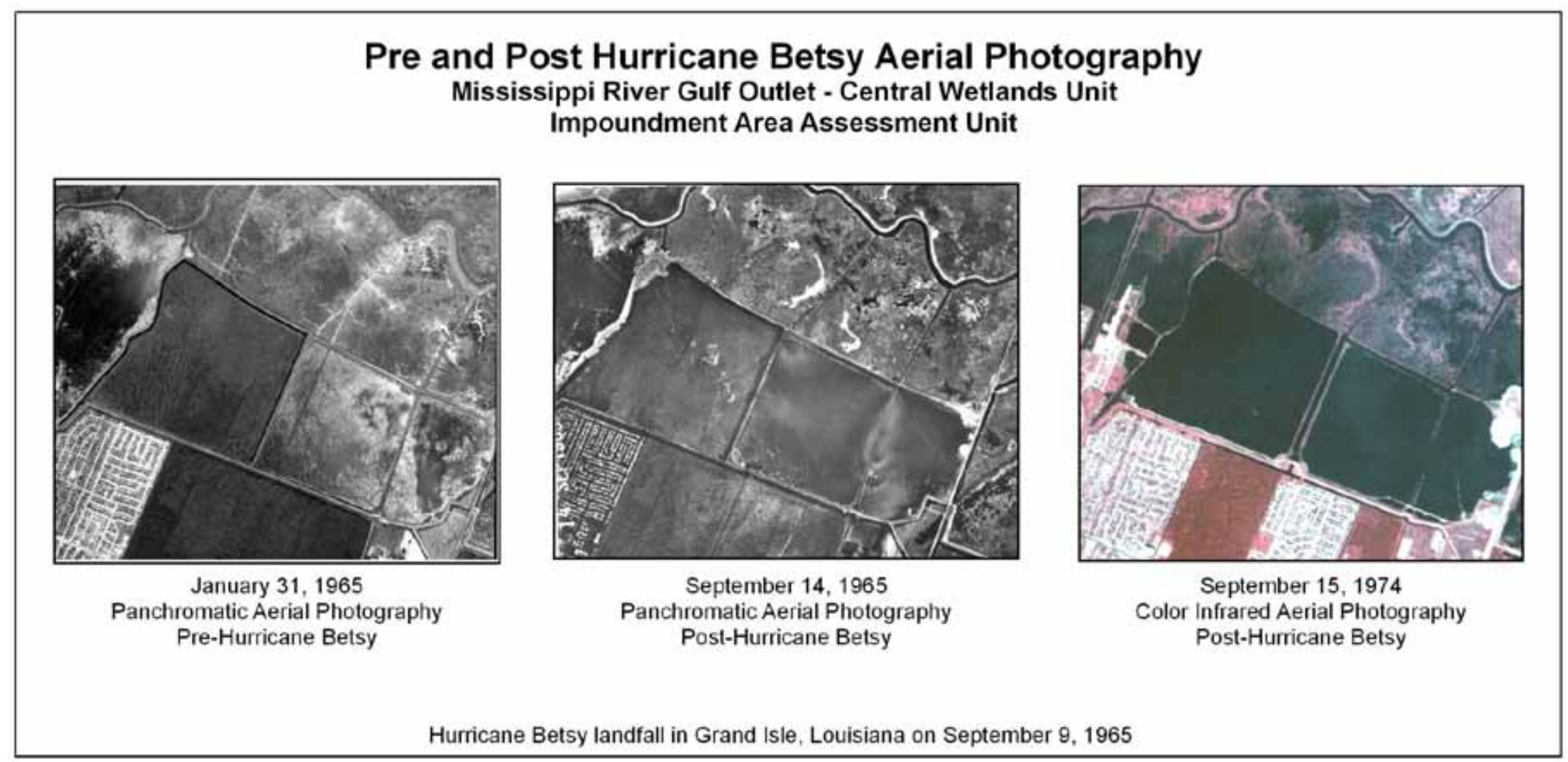

Figure A19. Mississippi River Gulf Outlet Impoundment Assessment Unit, Pre- and Post-Hurricane Betsy aerial photography. 


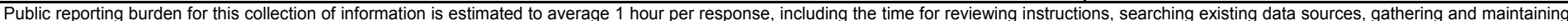

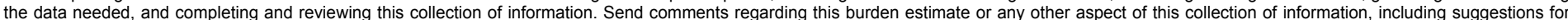

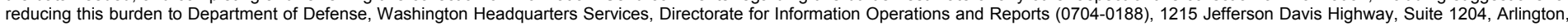

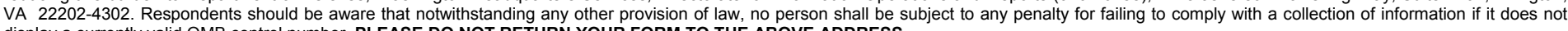
display a currently valid OMB control number. PLEASE DO NOT RETURN YOUR FORM TO THE ABOVE ADDRESS.

\begin{tabular}{l|c}
$\begin{array}{l}\text { 1. REPORT DATE (DD-MM-YYYY) } \\
\text { March } 2012\end{array}$ & $\begin{array}{c}\text { 2. REPORT TYPE } \\
\text { Final report }\end{array}$ \\
\hline
\end{tabular}

\section{TITLE AND SUBTITLE}

Land and Forest Area Changes in the Vicinity of the Mississippi River Gulf

Outlet, Central Wetlands Region, 1935-2010

3. DATES COVERED (From - To)

5a. CONTRACT NUMBER

5b. GRANT NUMBER

5c. PROGRAM ELEMENT NUMBER

\section{AUTHOR(S)}

Christina L. Saltus, Glenn M. Suir, and John A. Barras

\section{5d. PROJECT NUMBER}

5e. TASK NUMBER

5f. WORK UNIT NUMBER

\section{PERFORMING ORGANIZATION REPORT} NUMBER

Environmental Laboratory

U.S. Army Engineer Research and Development Center

3909 Halls Ferry Rd.

Vicksburg, MS 39180-6199

9. SPONSORING / MONITORING AGENCY NAME(S) AND ADDRESS(ES)

Headquarters, U.S. Army Corps of Engineers

Washington, DC 20314-1000
ERDC/EL TR-12-7

10. SPONSOR/MONITOR'S ACRONYM(S)

11. SPONSOR/MONITOR'S REPORT NUMBER(S)

\section{DISTRIBUTION / AVAILABILITY STATEMENT}

Approved for public release; distribution is unlimited

\section{SUPPLEMENTARY NOTES}

\section{ABSTRACT}

As part of the overall Mississippi River Gulf Outlet (MRGO) Ecosystem Restoration Study, the Central Wetlands Unit (CWU) is a critical coastal restoration project proposed to mitigate the effects of the MRGO dredging and dredged material placement in southeastern coastal Louisiana. An in-depth knowledge of recent and historical coastal landscape history is a key knowledge element required by project managers to make informed decisions for implementing the overall CWU restoration strategy. The goal of this study was to provide a refined landscape history for the CWU that both exceeds and supplements information provided by existing coastal habitat and land loss data sets. The research identified and quantified recent and historical land change trends and general forested wetland habitat changes within the CWU from 1935 to 2010.

The CWU land area changes were analyzed using a series of land-water data sets obtained from classified Landsat Thematic Mapper (TM) satellite imagery, historic aerial photography and topographic quadrangles. Wetland forested habitat changes were evaluated using two preconstruction (1935 and 1956) and two post-construction (1965 and 1974) data sets bracketing the construction of the MRGO (1965).

The study revealed that the CWU net land loss from 1935 to 2010 was 6,688 acres with a land area change rate of $-87.6 \pm 11.1$ acres/yr $\left(\mathrm{r}^{2}\right.$ $=0.68$ ). Rapid loss of forested habitat also occurred within the CWU throughout the 1935 to 1974 analysis period. In 1935 , the CWU consisted of 13,924 acres of forested habitat and by 1974 virtually all were lost. The primary events affecting historical landscape change within the CWU over the past 75 years are linked to (1) cumulative hurricane impacts causing physical removal of marsh, (2) partial flooding of impounded areas after Hurricane Betsy, (3) construction of the MRGO, and (4) salinity increases causing habitat conversion.
15. SUBJECT TERMS
Central Wetlands Unit (CWU)
Ecosystem restoration

Coastal restoration

16. SECURITY CLASSIFICATION OF:
\begin{tabular}{l|l|l|}
\hline a. REPORT & b. ABSTRACT & c. THIS PAGE \\
UNCLASSIFIED & UNCLASSIFIED & UNCLASSIFIED
\end{tabular}

17. LIMITATION
OF ABSTRACT

\section{NUMBER} OF PAGES

54 19a. NAME OF RESPONSIBLE PERSON

19b. TELEPHONE NUMBER (include area code) 